OCCASIONAL PAPER

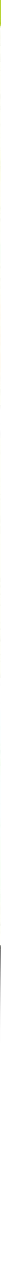

\title{
The impact of migration and remittances on natural resources in Tajikistan
}

Igor Rubinov
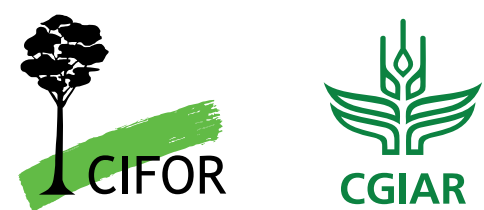



\section{The impact of migration and remittances on natural resources in Tajikistan}

Igor Rubinov

Princeton University 
Occasional Paper 164

(c) 2016 Center for International Forestry Research

(c) (i) Content in this publication is licensed under a Creative Commons Attribution 4.0 International (CC BY 4.0), http://creativecommons.org/licenses/by/4.0/

ISBN 978-602-387-049-3

DOI: $10.17528 /$ cifor/006348

Rubinov I. 2016. The impact of migration and remittances on natural resources in Tajikistan. Occasional Paper 164. Bogor, Indonesia: CIFOR.

Photo by Igor Rubinov/Princeton University

A large village of approximately 250 households in the Zarafshan mountains of northern Tajikistan maintains robust forest cover in the immediate vicinity of dwellings.

\author{
CIFOR \\ Jl. CIFOR, Situ Gede \\ Bogor Barat 16115 \\ Indonesia \\ $\mathrm{T}+62(251) 8622-622$ \\ $F+62(251) 8622-100$ \\ E cifor@cgiar.org
}

\title{
cifor.org
}

We would like to thank all funding partners who supported this research through their contributions to the CGIAR Fund. For a full list of CGIAR Fund Donors please see: http://www.cgiar.org/about-us/our-funders/

Any views expressed in this publication are those of the authors. They do not necessarily represent the views of CIFOR, the editors, the authors' institutions, the financial sponsors or the reviewers. 


\section{Contents}

Acknowledgments $\quad$ iv

$\begin{array}{ll}\text { Executive summary } & \mathbf{v}\end{array}$

1 Introduction 1

2 Migration in theory 3

2.1 Transnational migration 3

2.2 Circular migration 3

2.3 Multilocal mobility 4

3 Migration in practice - The case of Tajikistan 5

3.1 History of mobility 5

3.2 Contemporary migration 6

$\begin{array}{lll}3.3 & \text { Migratory hurdles } & 6\end{array}$

3.4 Remittances 8

$\begin{array}{ll}3.5 \text { Gender dynamics } & 10\end{array}$

4 Forest resources in Tajikistan $\quad 12$

$\begin{array}{ll}4.1 \text { History of Tajik forestry } & 12\end{array}$

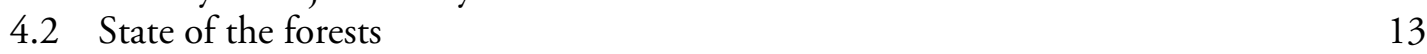

$\begin{array}{ll}4.3 \text { Land reform } & 15\end{array}$

5 Rooting mobility through forests $\quad 17$

$\begin{array}{ll}5.1 \text { Contemporary forest dynamics } & 18\end{array}$

$\begin{array}{ll}5.2 \text { Tree cultivation } & 19\end{array}$

$\begin{array}{ll}5.3 \text { Nutritional effects } & 19\end{array}$

$\begin{array}{ll}5.4 \text { Social remittances and forest resurgence } & 21\end{array}$

$\begin{array}{ll}6 \text { Conclusion } & 23\end{array}$

$\begin{array}{ll}\text { References } & 25\end{array}$

Appendix: Data sources in Tajikistan $\quad 30$ 


\section{Acknowledgments}

I would like to extend a heartfelt debt of gratitude to friends, colleagues and informants in Tajikistan who supported me and my research efforts. I would like to thank my advisors at Princeton University, Joáo Biehl, Lisa Davis and Serguei Oushakine for their indispensable guidance. I am also grateful for the funding I received for my dissertation research, from which this paper draws. Those funders include the
National Science Foundation, IREX (International Research and Exchanges Board), SSRC (Social Science Research Council) and the Princeton Environmental Institute. Finally, I am appreciative of the wonderful staff at CIFOR who gave me an opportunity to expound on this important policy issue as I wrote my dissertation, especially Christine Padoch, without whom this would not have been possible. 


\section{Executive summary}

This paper will outline the wide-ranging importance of migration in contemporary Tajikistan as it relates to forests, orchards and woodlands. After highlighting the theoretical links that underpin migration processes, connections will be drawn to practical conditions in the country. Given that three-quarters of the population live in rural areas, particular attention will be paid to the relationship of people to the natural resources that they manage and live amongst. A key concern of ecologists has been a decline in forest cover in Tajikistan following the Soviet Union's demise. However, land tenure reforms and post-war political stability portend nascent opportunities for investing remittances, labor and experience into agricultural and ecological resources - chief among them, woodlands and orchards.

The first section explores the global context and broader theoretical concepts that have expanded understandings of contemporary migration processes. Insight into migration as a transnational, multilocal and circular strategy will underscore its emergence as an adaptive and flexible means of securing a living.

The second section highlights the dependence of Tajikistan's post-independence labor force on migration to the Russian Federation. It explores how a visa-free travel regime, tied to onerous bureaucracy and punitive policing, has made circular migration from former Soviet states alluring yet precarious. Over the last two decades, these population movements have transformed economic, social and political opportunities in Tajikistan, the world's most remittance-dependent economy. Attention is paid to the challenges faced by migrants, the viability of remittance data and the gender dimensions of a male-dominated migrant stream.
The third section provides an overview of Tajikistan's forests and their management. A brief history of the institutions of natural resource management in the country and the region is followed by an accounting of forestry resources. With diminishing state capacity, natural resources have increasingly come under the control and management of small-scale land holders. De-collectivization of state land, initiated over a decade ago, has provided stable land leases to dekhan (private family) farms, allowing them to introduce long-term improvements to the land.

The penultimate section explores how the challenging demographic, sociopolitical and macroeconomic indicators explored in previous sections may be ameliorated by forestry and horticultural efforts emerging at the local level. As the reliability of labor migration to Russia decreases, these critical yet declining remittance flows will need to be invested in viable domestic enterprises. Despite a lack of experience and institutional support, Tajik households are beginning to invest in tree crops and utilize adaptive woodland management in pursuit of sustainable livelihoods. The conclusion underscores the economic, political and ecological conditions in Tajikistan that encourage migrants and sending communities to improve forest resources.

The critical intersection of migration, livelihoods and the environment in Tajikistan is the focus of this paper. The goal is to unpack the dynamics of their individual interactions and to identify the gaps in knowledge and data around this important nexus. While migration processes have been well documented, its effects on socio-ecological systems in Central Asia deserve greater scholarly and policy engagement than they have received to date. This paper seeks to fill this lacuna and inform natural resource management by highlighting the effects of population movements and their capacity to enhance ecological and social well-being. 


\section{Introduction}

For better or worse, Tajikistan has come to be defined by labor migration in the post-Soviet era. Unlike other countries that have promoted or welcomed emigration (such as the Philippines), this state of affairs has been driven by the cumulative effects of individual decisions rather than any coordinated policy. A debilitating civil war during 1992-97 left the country in ruins. Whatever infrastructure, investments and social systems had been put in place by the Soviet Union during seven decades of rule fell by the wayside. In the absence of significant natural resources, trade links or foreign investment (Tajikistan is landlocked and mostly mountainous), the economy collapsed. Millions of migrants from Tajikistan (as well as Kyrgyzstan and Uzbekistan) took on illicit, underpaid and insecure jobs in the most economically viable regions of the former Soviet Union. Traveling to the factory towns and urban metropolises of Russia became the dominant response to widespread poverty in postSoviet Central Asia.

These flows started timidly in the late 1990s, once the tumult of Tajikistan's 5-year civil war had settled into single-party stasis. Facing a dearth of domestic job opportunities, residents reconsidered their ties to the former colonial heartland. Tajik citizens were eager to take advantage of linguistic, cultural and transportation linkages to the Russian Federation, abetted by a visa-free travel regime. Labor migration to Russia underpinned a steady socioeconomic recovery, pulling nearly a quarter of the population out of extreme poverty (Olimova 2006). A small but steady trickle of remittances provided the ballast. By the end of the 2000s, Tajikistan had become renowned in policy circles as the world's most remittance-dependent country - perhaps ever. Before Russia’s financial downturn in 2014, migrant transfers topped 50\% of GDP. In the wake of macroeconomic and political crises, Tajikistan depended on remittances for $36.6 \%$ of its GDP in 2015 (World Bank 2016) - still the highest ratio in the world.
Despite turmoil in global markets and uncertainty in Russian migration policy, migration flows are unlikely to abate. Projections of contracting labor pools in Russia and an excess labor supply in Central Asia will continue to encourage migration for decades to come (UNDP 2015). Furthermore, seeking work in Russia has become a widespread norm that defines the aspirations of young workers, their parents and their communities. However, despite growing circulation, Tajikistan is still primarily a rural country: $73.5 \%$ of the population lives in the countryside (TAJSTAT 2015a). Migrant remittances form the backbone of these household economies (Olimova and Bosc 2003; Mughal 2006; IOM 2009c). Given the changes to rural livelihoods in the era of migration, the relationship between mobility and ecological resources has grown ever more important. As the heavy hand of Soviet bureaucracy has faded, local populations have taken on responsibility for planning, irrigating and improving the landscapes that they live in. Faced with a limited and underfunded government presence in outlying regions, local residents have emerged as the primary managers of ecological resources.

In resource-poor and economically marginal regions of the world, such as Tajikistan, migration has been a lifeline for household welfare. Tajik migrants are motivated by a variety of outcomes: to erect or renovate a home, underwrite lifecycle celebrations (such as weddings, funerals and children's ceremonies), or to establish an identity as a successful migrant for their eventual return. A variety of investments beckon the mobile incomeearner. While the majority of remittances are spent on daily necessities such as food, clothing and household items, migration is usually tied to long-term saving strategies centered on livestock acquisition, seeding entrepreneurial initiatives (such as a taxi or a small shop), improving agricultural holdings and housing investments (Olimova et al. 2010). Part of the agricultural diversification being explored by communities in Tajikistan involves the 
investment of migrant earnings, labor and land into horticulture (fruit tree cultivation) and silviculture (the management of forest lands).

Rural families throughout Tajikistan grow vegetables and fruits in kitchen gardens. In low-lying, irrigated valleys cotton and other annual crops are tended, while the upland mountain regions have focused more resources on livestock and horticulture. Recent years have witnessed a decline in state-mandated cotton production alongside a diversification of agricultural outputs (Martius et al. 2012). As households increasingly turn to farming, shepherding and orchard keeping to support migrating family members, Tajik residents have taken on a larger role in natural resource management throughout the country. This is evident not only for land holdings adjacent to homes that have been privatized in recent years, but also for the river banks, forests and pasturelands that surround rural villages. The distributed and often uncoordinated activities of Tajik people are key determinants of ecological conditions in the country. Based on insights from the author's research, investments in agriculture in general, and sylvan regeneration in particular, may offer a valuable way to mitigate migratory uncertainty by diversifying ecological productivity.

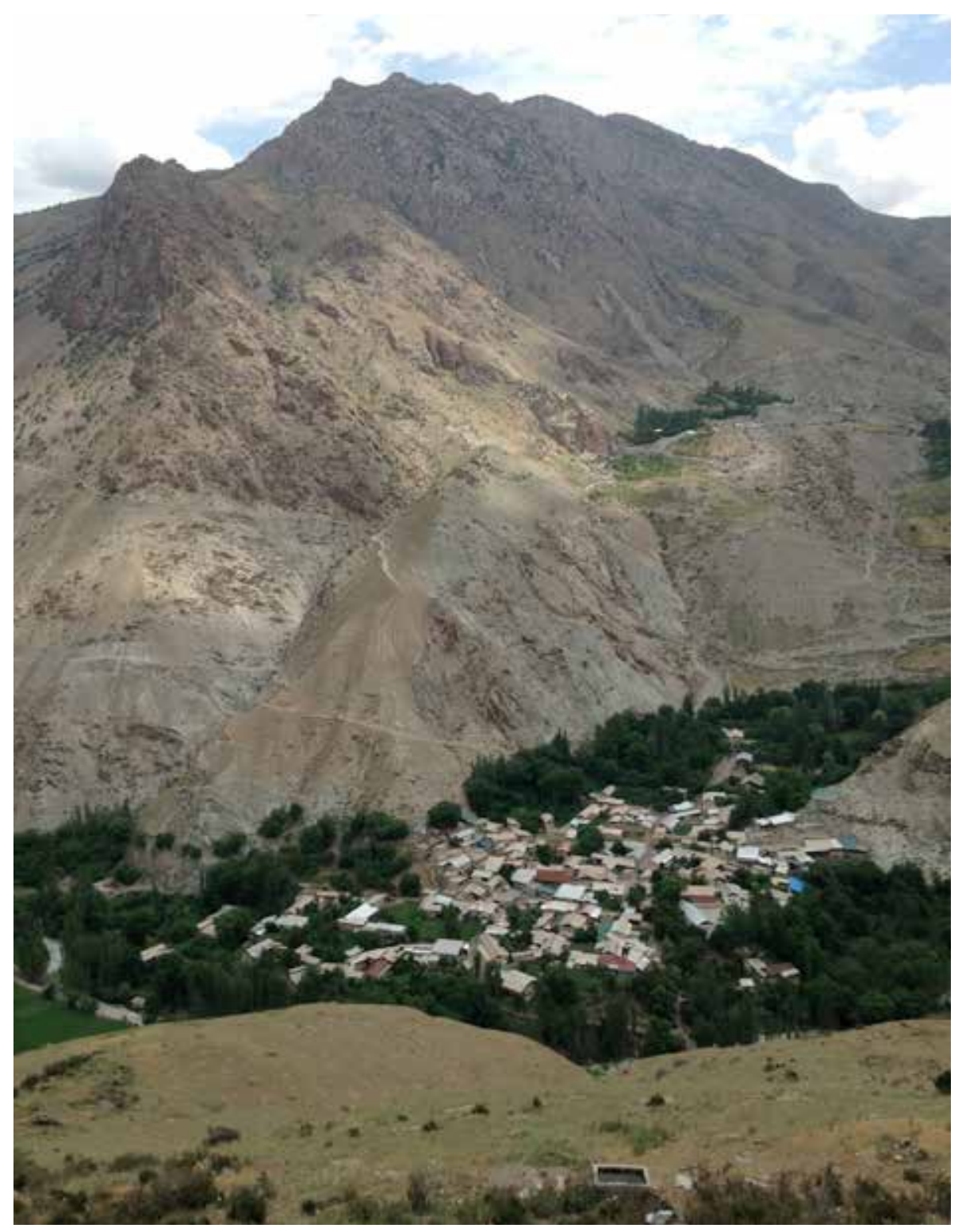

A large village of approximately 250 households maintains robust forest cover in the Zarafshan mountains. Upstream, a smaller village of only $\mathbf{3 0}$ households with a very limited water supply cannot sustain many trees. (Photo taken by the author) 


\section{Migration in theory}

The world is connected. Despite tendencies in the social sciences of the 20th century to focus on stable and bounded places and people, mobility and fluidity are now central components of analysis. Migration is not an aberration or deficiency of global systems but a constitutive element of them. There are no longer questions as to whether globalization is an underpinning of the modern world, only how many centuries ago it began. As the debates over globalization have receded in the rearview mirror, there is little doubt that the world is more closely interwoven, through the mobility of people, capital and ideas. Of course, obstacles and preferential pathways continue to differentiate who wins and who loses from these flows. The characteristics of who moves, across what borders, and under what authority continue to matter a great deal. In recent decades, patterns and theoretical considerations have been developed to account for evolving mobility dynamics.

\subsection{Transnational migration}

The propensity of migrants to travel across borders does not signal the demise of nation states (Bauböck 2003), as some political scientists had warned. The control of movement across borders continues to be a key element of nation states' constitution and function. Who migrates, for what reasons and with what outcomes, is usually conditioned by a range of macro-scale factors, which are in turn mediated by contexts and realities at a more grounded level (Black et al. 2011). Thus, mobility, and its constraints, are a crucial arena for managing people and territories. Transnationalism is a concept that stretches what it means to be situated by highlighting how people can be connected across vast spaces. But rather than an overarching concept that helps to explain how $3 \%$ of the world's population are migrants (IOM 2015), transnationalism has helped to highlight the interrelations between migration and family dynamics (Basch et al. 1994; Portes et al. 1999; Goldring 2001). As families reconsider their options beyond the bounds of where they are currently located, livelihood practices cross geographic sites and spaces, giving rise to relational and fluid social fields where family does not connote proximity (Olwig and Sørensen 2002; Landolt and Da 2005).

Families that, at first glance, seem to live traditional peasant lives tied to the land, in fact have livelihoods that work across scales (Chambers and Conway 1992). Transnational livelihood strategies can help to explain how people 'jump' or move across different scales (Bebbington 2000) or live in multiple places simultaneously. Migration across borders often provides the best means of maintaining sustainable rural livelihoods by relieving population pressures and providing additional incomes from distant labor pools (Scoones 1998; Ong 1999). Rural and urban households are able to juggle multiple forms of capital, coming from distant and local places, through various kinds of labor (Bebbington 1999; De Haan and Zoomers 2003). The diversification of economic activity is necessary for households to increase their capital base (Scoones 2009). However, these efforts should not be valorized simply on account of their flexibility, as they can also cause economic uncertainty and loss of onsite labor, and place significant strains on various forms of emotional and familial care. Transnational relationships can often lead to 'stretched' families that need to make constant adjustments across space (Yeoh et al. 2005). These efforts, as they become habitual, can lead to circular migration.

\subsection{Circular migration}

Circular migration refers to the practice whereby migrants frequently return to their sending communities. People may choose to return for holidays, family occasions or to minimize expenses between jobs at costlier sites. Whenever migrating 
back and forth between sending and receiving countries is possible, it gives people more choices, thereby improving their capabilities (Newland 2009). Evidence from cases where migration faces fewer barriers suggests that circular migration is an attractive (and even preferred) option. According to surveys conducted across the former Soviet Union, where freedom of movement is relatively unconstrained for former Soviet citizens to the Russian Federation and other countries in the Commonwealth of Independent States (CIS), a strong majority of potential migrants would prefer short periods of work abroad, followed by return. More than $60 \%$ of migrants in Bosnia and Herzegovina, Romania, Georgia, Bulgaria, the Kyrgyz Republic and Tajikistan preferred such an arrangement (Mansoor and Quillin 2007, 110). Circular patterns allow workers to take on seasonal or temporary jobs that take advantage of regional employment differences and their attendant differentials in wages and living costs. Migrants may depart with a set objective (such as a certain amount of savings) - which may take them several migration cycles to achieve - allowing them to return permanently upon achieving that objective (Cassarino 2008). The end of circulation can be occasioned by such 'success' or by myriad impositions that stop circulation in its tracks.

\subsection{Multilocal mobility}

Part of how people adapt to changing and challenging circumstances is by recalibrating where and how they live and work. Migration processes can have varying intervals: temporary, cyclical or permanent. The laws and priorities of sending and receiving countries, dictated by legal institutions and policing agencies, influence how people manage mobility. Migrants take up a variety of tactics in response, be they formal or informal, legal or illicit. While migration has become a common dimension of livelihoods that maintains links across borders, these strategies are not exclusively international. In fact, they are frequently tied to internal migration - which may or may not act as a springboard for further travel abroad. As a result, transnational migratory pathways are often extensions of multilocal households (Thieme 2008), which connect internal and international migrations (Skeldon 2006).

Family members may live and work in different places, requiring that care be extended to their children and elderly relatives across space. The dispersal of families does not mean that everyone shares equally in the capital and assets that circulate (Tiemoko 2004). Hierarchies and power dynamics across generations, genders and legal statuses frequently disturb equitable or desired remittance allocations (Chant 1998; Mattingly 2001). For instance, notions of masculinity are reinforced in the 'rite of passage' that migration from Mexico to the USA entails (Goldring 2001), while women face patriarchal restrictions that seek to maintain appropriate femininity norms (Kanaiaupuni 2000). In contrast, women from the Philippines benefit from state-supported migration programs (Tyner 1996; Parreñas 2001) and face little societal or institutional pressure in seeking to work abroad. The maintenance of relationships in multilocal households may prove beneficial to individuals and help support communities, at the same time as these processes also destabilize social norms and expectations (Wong 2006; Rubinov 2014). The variability in social relations occasioned by migration is also the product of structural factors.

Migration is undertaken in the hopes of bolstering livelihoods, investments and resilience. It is a tactic that is highly vulnerable to international policies, regional conditions and local practices. Furthermore, migration can be incredibly important not only for migrants themselves but for their families and wider communities, by stimulating economic growth, enhancing workforce skills, alleviating unemployment, and reducing poverty in home and host areas (de Haas 2007). The individuals and families that lie at the heart of migration undergo great stresses, yet also gain knowledge, skills and valuable networks in the process. The costs and benefits are often distributed unequally and depend on factors beyond migrants' control (Martius et al. 2012).

Thus, it is illustrative to look at the case study of Tajikistan, the world's most remittance-dependent economy, to better understand how migration can be interwoven with livelihoods and ecological resource use. The significant difficulties associated with migration to Russia (and to a much lesser degree Kazakhstan), necessitate creative and adaptive relationships with local economies, which, in the case of Tajikistan, are deeply connected to land and ecological resources. Increasingly, migration and forestry dynamics intersect. However, links between forests and migration have been overlooked in the literature on migration, as well as in discussions about forest-based livelihoods (Hecht et al. 2015, 142). This paper seeks to address this research gap by considering an understudied dimension of migration in Tajikistan - its interaction with forests. 


\section{Migration in practice - The case of Tajikistan}

The remittances of labor migrants from Tajikistan have been unprecedented in their relative scale and economic impact. No other former Soviet state has witnessed the migration of one out of every five members of the workforce, nor has any other country on Earth relied on remittances for half of its gross domestic production. After a tentative peace agreement took hold following the cessation of the civil war in 1997, Tajikistan quietly started exporting people. As this section will explore, bureaucratic difficulties have emerged as the migrant stream has grown in prominence. Furthermore, the widespread mobility of such a large portion of the Tajik population has also had significant effects on gender dynamics and socioeconomic well-being. Some of these elements are evident in the available literature. However, gaps in the areas of remittance accounting and household outputs remain.

\subsection{History of mobility}

Significant population movements preceded this relatively recent labor migration phenomenon. The territory of modern-day Tajikistan was inhabited by sedentary agriculturalists who faced waves of conquest during the second millennium by Mongols, Turks, Persians and others. While the rest of post-Soviet Central Asia adopted Turkic languages (which are mutually intelligible), the people living in Tajikistan adopted Persian. ${ }^{1}$ Not practicing the nomadism found among Kyrgyz and Kazakh populations, most of Tajikistan was beholden to regional khanates (based in Bukhara

\footnotetext{
1 This excludes residents of the Pamir Mountains who have maintained nearly a dozen of their own languages to this day. These communities are found in the GornoBadakshan Autonomous Oblast, which comprises $45 \%$ of the country's territory but only $3 \%$ of its population, alongside a small population of ethnic Kyrgyz in the high mountain Murghab plateau.
}

and Samarkand, in present day Uzbekistan), which taxed the agricultural outputs of their subjects. Thus, there were no sedentarization programs to be deployed by Soviet planners, as there were for Tajikistan's neighbors. Instead, waves of skilled technicians (predominantly Russian) and relocated minorities from elsewhere in the Soviet Union (such as Volga Germans, Tatars, Koreans, Jews, etc.) found their way to Tajikistan's nascent cities and industrial sites and to lowland valleys, where massive irrigation projects and huge cotton plantations were being established. ${ }^{2}$

Following the outbreak of civil war in 1992, the vast majority of Russians and resettled minorities fled the country (IOM 2009b). Having taken significant expertise, capital and connections with them, the industrial enterprises staffed by this managerial class mostly fell into disrepair. In the absence of viable domestic industries, and after a punishing half decade of violent conflict, salaries collapsed. By 2000, the average income per person amounted to only 3.6 Tajik som per month (compared with 115.9 som in 2014) (TAJSTAT 2015b, 15). ${ }^{3}$ Labor migration to relatively more prosperous sites in Kazakhstan and the Russian Federation started apace in the late 1990s and accelerated quickly. By the mid-2000s, Tajikistan was reportedly sending over a million people a year to Russia - out of a country of seven million people (Mansoor and Quillin 2007).

2 The bewildering borders of contemporary Tajikistan have also led to sometimes violent conflicts with neighboring Uzbekistan and Kyrgyzstan - particularly along the edges of enclaves and exclaves found in the Ferghana Valley. These ill-conceived borders have led to significant transboundary flexibility requiring no small amount of 'border work' on the part of local populations (Reeves 2014).

3 In 2014, 1 US dollar was equivalent to roughly 5 Tajik som. 


\subsection{Contemporary migration}

This far-reaching migration strategy was bolstered by the fact that most Tajiks spoke Russian as either their first or second language. Furthermore, visas were not required for former Soviet citizens to travel to the Russian Federation. These legal openings were compounded by a transportation infrastructure that allowed for relatively cheap access to Russias major cities by rail, air or bus. Migrants were also encouraged by the close cultural affinity they shared with their former Soviet counterparts. Many had contacts, either through family members, acquaintances who had fled Tajikistan during the war, or comrades they had served alongside in the Soviet Army. Existing technical, trade and mechanical skills were acknowledged at Russian work sites - with most migrants taking jobs in construction or as manual laborers and petty market traders (Ryazantsev 2013; Boyko 2015) ${ }^{4}$ - although many skilled migrants had to take jobs below their qualification levels. Having been raised most of their lives within a Soviet system that promoted a 'friendship of nations' (druzhba narodov), Central Asian citizens felt like they understood Russian norms, codes and expectations - something that could not be said for other nearby countries such as Iran (despite sharing the Farsi language) or China. It was in many ways a clear economic proposition as well. By the late 1990s, Tajik migrants faced devastation, ruin and rampant unemployment in their sending country, while the Russian economy was beginning to enjoy strong economic growth on the back of natural resource exports. Labor shortages, particularly in low-skilled and low-paid positions, beckoned. Given Russia’s relatively lax migration policies early on, Tajik men who had not been able to sustain their households through a decade of independence took whatever jobs they could find in a land that felt close to home.

Migrants from Tajikistan were mainly from rural areas and overwhelmingly male - such that women only constituted $6.5 \%$ of migrants (IOM $2009 \mathrm{~b}$ ). The educational level of migrants was above the national averages: $22.3 \%$ of them had a university background and $76.2 \%$ had secondary schooling (Olimova and Bosc 2003). They were often the primary breadwinner in the family and

4 A total of $74.1 \%$ of migrants worked in construction, while wholesale and retail trade accounted for $10.8 \%$, industry $4.8 \%$, agriculture $5.4 \%$, and other sectors (services, education, etc.) comprised 4.8\% (Olimova et al. 2010, 5). undertook migration for $1-3$ years, to test out the waters and see how much they could earn (Olimova 2006). These pioneering migrants traveled with the intent of addressing serious shortcomings in their families' coffers.

However, by 2001 the median age of migrants began to decrease. As the migrant stream became more entrenched and the network of connections became more robust, younger men began to see it as their primary career pathway. With paltry salaries and few functioning enterprises in Tajikistan, young men began to forego even the last years of secondary school to start earning money in Russia (Olimova and Kurbanova 2006). In the new millennium, those under the age of 30 became the dominant age group among migrants traveling abroad for the first time (Olimova et al. 2010, 4). By 2005, of those who traveled abroad to earn money for the first time, $88 \%$ were under 30 years of age (IOM 2006, 35). While the economic benefits became increasingly significant, there were many institutional and social challenges that weighed on these young men and their families.

\subsection{Migratory hurdles}

After labor migration became a widespread and entrenched phenomenon, Russian policy became more aggressive and unwelcoming. The Russian Federation's police forces, border officials and judicial system hounded migrants hailing from former Soviet territories and the Caucasus. While the visa-free regime had allowed them to enter with relative ease, the documentation required for legal employment and proper residency were onerous at best. Many migrants simply gave up trying to get every paper signed each time they moved abroad or changed positions. Many were left destitute by the constant harassment from officials seeking bribes and payments - or by crooked employers who would face no retribution from the justice system (Marat 2009). Not only were migrants cheated by their employers and constantly harassed for bribes, they were also under threat from gangs of xenophobic skinheads in Russian cities (RFE/RL 2010). Interviews conducted by the author confirm that these difficulties were exacerbated by laws that were frequently in flux (e.g. Government of the Russian Federation 2014 a, b, c), while the police manipulated this ambiguity for personal gain.

The tightening of the migration regime in the Russian Federation over recent years (and especially in 2015) is significant. Prior to 2010, migrants seeking legal 
employment in the Russian Federation had to obtain a work permit (quota) from the Federal Migration Service, which was fairly easy to do. Even without a work permit, migrants from Tajikistan could, as usual, enter the Russian Federation (and Kazakhstan ${ }^{5}$ ) on a visa-free basis. However, since 2010, two forms of work permission have been issued in the Russian Federation (and Kazakhstan): permission to work for physical persons (patents) and for legal persons such as companies (a permit or quota). Whereas the process of obtaining quotas was complicated and expensive, obtaining a patent was less so. As a result, the numbers of patents issued during 2010-2014 increased 20-fold - even though many of their holders continued to work for legal persons (thus, technically, in violation of the law) (UNDP 2015). As of 2014, their stay in these countries could not exceed 90 days without additional documentation. Furthermore, beginning in 2015, in order to receive a patent to work in Russia, migrants had to demonstrate competency in an exam of Russian language, history, culture and civic education. More onerously still, as of January 2015, migrants from the Kyrgyz Republic, Tajikistan and Uzbekistan required newly issued biometric passports, forcing all wouldbe migrants to apply for new passports (UNDP 2015). The latest series of requirements have added extra uncertainty for migrant trajectories - particularly as a 'black list' of migrants banned from entry now awaits them at the border (Tursunov and Ibraimov 2014).

In response to this ensnaring web of bureaucracy, many migrants used long-term strategies to gain some semblance of security. A significant number have taken up Russian passports, which removed most of the paperwork demanded of foreign workers (gasterbaiteri). This policy was promoted in particular in the mid-2000s when Russia feared a decline in the population replacement rate (MiRPAL 2015), but acquiring a passport has become increasingly more difficult as the population collapse has grown less acute. Another common strategy was to live with a Russian citizen. An IOM (2009a) study found that up to onethird of married men who left Tajikistan to work abroad did not return home. Many households

5 Labor migration to Kazakhstan has always been the second-most prominent destination, but its relative importance is dwarfed by Russia's. Less than $5 \%$ of migrants travel to Kazakhstan for work (Olimova 2006). lost contact with their migrating family members and second marriages in Russia became a common phenomenon (Olimova et al. 2010). Living with a 'second wife' "was largely confined to the relatively small group of more established migrants: those who felt at home in the city; who enjoyed the privacy of an apartment; and whose earnings allowed them some degree of material comfort and security" (Reeves 2011, 572). Since most migrants were uncertain about their prospects abroad, family members left behind could not really tell if their husbands fell into this category, or what their work status actually entailed (author's interview 22 May 2015). To add to the uncertainty, migrants frequently abandoned their Russian families once they had decided to stop working abroad. These domestic arrangements created considerable anxiety for women in both sending and receiving countries (Reeves 2011). The men could use their transnational mobility as a lever with relationships at both ends.

The situation was particularly dire for Tajik women, who often had no recourse and limited social or legal means of redress. Once 'abandoned,' wives faced grave difficulties in remarrying, owing to the stigma of divorce, and often had to move back in with their natal household. Moreover, if their marriages were not formally registered with the civil authorities, as was the case for some Islamic marriages, these women could not lay legal claims upon their (former) husband's property or gain rights to child assistance payments. Even in households where remittances were a net positive and the migrant's return was not in doubt, "children are often affected negatively by the absence of a parent, with a particular impact on their psycho-social well-being" (UNICEF 2011, x). For many reasons, migration to Russia is extremely difficult for the migrants and the households awaiting their return. However, knowing these challenges did not prevent a vast portion of the Tajik labor force from working abroad.

There are also important internal migration dynamics, highlighted by the prevalence of circular and multilocal livelihoods in Tajikistan, which underpin international migration. There is a history, especially in Tajikistan's mountainous regions, of diversifying household income by sending family members to work elsewhere (Tadjbakhsh 1996). Unfortunately, as in other countries, there are very few statistics on the topic. It is difficult to track internal mobility 
without in-depth social science research. The author's ethnographic research suggests that many households have family members in cities and occasionally in other rural regions. Migrants often leave from or return to sites that are not their natal home. These links are reinforced by social remittances and the circulation of fruits, nuts, people and money. Households stretched across Tajikistan and the former Soviet Union facilitate widespread labor migration.

These multilocal households still face significant economic pressures, despite the gains Tajikistan has made in the last decade. Multigenerational households can usually expect a very basic income in the form of a pension for the eldest members ( $\sim$ USD 40/month). Working age members will try to secure local jobs with government agencies (such as a school, local administration or a road maintenance crew). These meager salaries are offset by their stability. Larger income generation may come from labor migration, transporting and trading market goods, or buying a vehicle for use as a taxi (public transportation is nonexistent in the countryside). These purchases carry risks and often require upfront capital. Whether a household is trying one of these money-making strategies or just trying to get by, households will invariably have a garden and, commonly, work an agricultural field. ${ }^{6}$

Tajik gardens, fields and orchards produce an impressive array of goods despite continuing government mandates to grow cotton in lowlying regions (Conrad et al. 2016). These outputs are first and foremost directed toward meeting household subsistence and have traditionally not generated significant incomes (Rowe 2009), owing in particular to the low wholesale prices for produce. Children often help with domestic labor, informal market work, and almost always with agricultural production. However, this mix of household labor is rarely enough to allow families to save or pay off debts, which are increasingly common given the availability of micro-credit agencies and banks (charging up to $30 \%$ annual interest). As a result, labor migration, particularly by younger adult males in the household, has become prominent. The major outcome of their toils is remittances.

6 This does not apply to urban residents, who must rely on rural relatives and urban incomes for their subsistence food products. As mentioned above, urban residents account for a quarter of Tajikistan's population.

\subsection{Remittances}

Remittances to Tajikistan are staggering in their importance. Cash transfers traceable through the banking system are five times greater than externally financed public investment and 10 times higher than foreign direct investment (Kireyev 2006, 6). This remarkable inflow of wealth was fueled by an estimated one million Tajiks residing or moving seasonally abroad for work (IOM 2014). That figure was equivalent to $17 \%$ of the whole economically active population and 28\% of working males (Mughal 2006). The latest available figures point to a marked downturn in remittance flows attributable to various fiscal shocks in Russia, which absorbs the lion's share of Tajik migrants (over 90\%). The latest available figures suggest that $36.6 \%$ of Tajikistan's GDP came from remittances in 2014, totaling USD 3.3 billion - down from an all-time high of over $\$ 4.2$ billion the previous year (World Bank 2015).

To help lend some context to these vast sums, the average transaction was only USD 275 spread across 15.2 million remittance transactions in 2013 from Russia to Tajikistan (UNDP 2015, 26). The Tajik economy was being propped up by money transfers amounting to a few hundred dollars sent a handful of times a year. This radically dispersed distribution of wealth had important socioeconomic consequences. The rate of poverty in Tajikistan dropped from $86 \%$ in 1999 to $57 \%$ in 2004 , and extreme poverty fell even more dramatically from $36 \%$ to $18 \%$ (IOM 2009c, 44).

Owing to the importance of migrant dynamics, policy analysts have become deeply interested in the potential of remittances as a force for economic revitalization. With the realization that migrant remittances account for more than official foreign aid (Ratha 2003), a 'remittance euphoria' took hold (de Haas 2005), promising more equitable and sustainable wealth creation than traditional foreign aid. However, this enthusiasm has given way to vacillating perspectives on remittances - what Hein de Haas (2015) has called a "remittance pendulum" - from brain drain pessimism to migration-for-development enthusiasm. Ultimately, the underlying institutional and political conditions in a sending country, and that country's legal relationship to the receiving country, determine whether remittances help to alleviate the existing structural deficits that initiated large-scale migration. Part of the academic uncertainty stems from the limitations and important gaps that exist surrounding migrant flows and their attendant remittances. 


\section{Limitations of remittance data}

Much of the data on remittances come from international organizations such as the International Organization for Migration and the World Bank. These agencies receive most of their data from government institutions. Unfortunately, most states have not systematically integrated migration into their frames for collecting agricultural, economic and population data (Hecht et al. 2015). Part of the informational lacuna lies in the fact that formal and legal figures on international migration and financial transfers are appreciably better than those that measure internal movements, illegal migration and transfers that evade formal pathways. Ultimately, remittance figures are estimates, and the enthusiasm or pessimism they occasion are guesses taken at overall trends.

Taking data from official channels, the median amount remitted per migrant in 2008 was 3608.2 somoni (USD 1080) (IOM 2009b, 12). Due to inadequate data at the household level in urban and rural areas, there is only a rough estimation for the average per capita amount dispersed among the population: an average USD 285 per capita at the country level (IOM 2009b, 35). From survey data, it appears that remittances of under USD 1000 a year tend to be spent mostly on consumption, primarily food, clothing and medical care (Taylor 1999). Remittances of USD 1000-5000 tend to finance durables, such as appliances and cars or are used to invest in home repairs and improvements. Remittances exceeding USD 5000 are mainly used to invest in rural house construction, while those exceeding USD 10,000 are invested in the remodeling of city apartments and larger-scale imports (Kireyev 2006, 14).

However, migrants also use significant resources for wedding celebrations and other festivities, known collectively as toi. The responsibility of migrants to invest in communal celebrations has been seen to be of such concern by state policy makers that the President of Tajikistan passed a law in June 2007 strictly curtailing toi expenditures. These rules, known as tanzim, are inconsistently enforced but they have limited the spending of migrants and local residents perhaps simply by allowing a pretext for avoiding significant spending, as the wealthiest community members seem to broach the limitations regardless.
A significant challenge in trying to calculate remittance flows is distinguishing them from funds used by traders settling accounts abroad. For instance, shuttle trading, the small-scale import of goods by individuals to take advantage of price differences, is quite common between Central Asian countries and Russia, as well as China. According to estimates by the National Bank of Tajikistan, such trade-related payments may represent up to $40 \%$ of total remittances (Kireyev 2006, 7). As a result, it is often difficult to disentangle what constitutes payments to family members and which remittances are part of business transactions. In an effort to separate commercial transactions from private remittances, the National Bank of Tajikistan decided to classify all single transfers of less than USD 1000 plus $50 \%$ of transfers between USD 1000 and USD 3000 as workers' remittances. The other $50 \%$ of mid-size transfers and any transfers of more than USD 3000 were reclassified as exports (Kireyev 2006). These assumptions were based on a survey but were rough estimations at best. Furthermore, these estimates obscure the fact that for relatively large amounts, often in excess of USD 3000, an illegal money transfer network known as perekidka (from the Russian for throwing or juggling) is often used (Kireyev 2006, 9). To avoid detection and to hide their larger earnings, shuttle traders and workers dissemble larger sums through illicit means, seeking to hide their trace. Given the low level of trust that people place on state and private banks in Tajikistan, it is particularly hard to follow money flows through the licit economic system.

The spending of remittances often involves a difficult balancing act between the desires of the migrant and the needs of their sending household - particularly the parents. Constant negotiations and compromises are needed between migrants and their families. These tensions are not simply in play in limitations or determinations of money flows. For instance, in Albania, return migrants from Greece are deeply invested in building homes in sending communities (Delakoglu 2014). Even though many of the migrants do not plan to live there, the transport of building materials and steady construction of these show-homes enables an act of dwelling that helps distant community members feel connected to the place. In Tajikistan, sons return, with construction experience in hand, to remodel part of their parents' homes or to add on home extensions. Other demands, such as the procurement of livestock (Light 2012) or 
participation in lifecycle rituals (Rubinov 2014) allow migrants to feel connected to their home communities despite their habitual or prolonged absences. These processes are constitutive of transnational links even if they do not show up on the remittance ledger.

\subsection{Gender dynamics}

One of the defining elements of migration dynamics in Tajikistan is the heavily skewed gender disparity. From the beginning, nearly all of the Tajiks traveling to work abroad have been male - an estimated $83 \%$ of migrants were male in the early 2000s (Olimova 2003), a figure that grew to $95 \%$ by decade's end (IOM 2009a). To be sure, a patriarchal social system that encourages men's mobility while restricting that of women is a leading cause. In Tajikistan, patrilocal marriage customs require women to travel to the home of their groom and take on a significant load of household labors, as well as bearing children. As a result, women tend to come under the conservative demands of their parents-in-law, who are disinclined to allow their domestic laborers (and dependents) to leave the household (Reeves 2011). The anticipation that a son and his wife will live with the parents is typically strongest for the youngest son - who is expected to live with his parents till their passing - but applies almost universally to women living in patrilocal household arrangements. ${ }^{7}$ Women are not considered to be heads of their households when the husband is absent. The in-laws typically take on such a role and assume control over remittances sent by their sons (ODIHR 2012, 6). If a husband would like to migrate semipermanently or become a Russian citizen, he is likely to ask his wife and their children to move abroad and set up a life there. However, circular migration, along with the dangers and freedoms it affords, is largely Tajik men's responsibility. For almost all women in Tajikistan, travel abroad is possible at the discretion of their husband (and his relatives). This highly gendered mobility pattern has significant consequences for how the resulting remittances are managed in migrant-sending households.

7 The rare exception might be a woman who has divorced and managed to find an income source on her own.
As noted above, the poverty rate has dropped significantly since remittances began to fill the coffers of migrant-sending households. Migration is particularly effective as a development tool because there are so few intermediaries in the allocation of cash - which, in Tajikistan, is either wired to the parents of the migrant or saved by the migrant himself. The parents may have full control over the amounts that are sent back, or remittances may be allocated in coordination with the migrant. If there are larger projects in mind, such as home construction, marriage/ funeral ceremonies, agricultural or entrepreneurial investments, etc., then the migrant will usually return with a large sum in his luggage, rather than paying transaction fees to money-transfer operators. Ultimately, young men and their parents, or older migrant men who are themselves household heads, will decide how much to remit, how much to save, what the distribution mix should be and when the migration process may have run its course.

When women play a role in these decisions, it is almost exclusively the oldest and most respected women in the household (Reeves 2011). Even for them, it is not always easy to sway the desires of the young men who have emigrated. Tajik male migrants often establish alternate or secret families in Russia, fall into debt, or struggle with exploitative employers and legal institutions. While their remittances are sorely needed in Tajik households, the men are struggling abroad and not always eager to fully disclose the extent of their successes and failures (Kroeger and Meier 2011). Fissures and traumas emerge in households as the chasm of spatial and cultural distance take their toll (Hegland 2010). Whether migrant men share information and money freely or not, it is almost always the case that someone has to take up the slack for their absence in the domestic and local economy. Most often, the younger women who had little say in the migration process are the ones called up to buttress local efforts.

There have been significant debates in the literature on gender and migration regarding the effects of workforce participation. Some scholars argue that individuals from households who have remitters abroad are less likely to be employed (Acosta 2006; Lokshin and Glinskaya 2009; Justino and Shemyakina 2012). Male-dominated migration has often led to more female-headed households and the feminization of agriculture 
(Bonin 2014; Kuvatova 2014). Remittances tend to decrease relative to increases in the age and education level of the household's head and are higher for households headed by women (Justino and Shemyakina 2012,13). Others find that households where women become the head are more likely to take on extra work (Chang et al. 2011). ${ }^{8}$ Furthermore, an increase in women's labor driven by migration may even have negative implications for socio-economic development in Tajikistan since women's work is often unpaid and remittances can be erratic (Kan n.d., 13). Wives of Tajik migrants surveyed by the IOM (2009a) noted that the remittances received were often insufficient to pay for basic necessities because the frequency of remittances varied and some women received no remittances at all. For many women in migrant-sending households, extra work is a necessity when faced with the prospect of one or several men leaving home.
Thus, migration does not necessarily favor women's empowerment or income generation when their husbands or male family members travel abroad. Men's remittances may be neutralized by the cost of traveling abroad, because of foregone local wages (which women are often unable to secure in their stead) and the fact that women take on a greater burden of domestic work after departure. However, migration may not even be the determining factor for women's workforce involvement. When a Tajik household has a farm, women have a greater amount of work regardless of whether there are any migrants (Kan n.d.). Because farm work generally involves low-skilled labor, women and children are common substitutes for nonmigrants in farm work (TAJSTAT 2015b). Faced with men's migration, raising children and farm work become women's primary domestic responsibilities $(\mathrm{Mu}$ and van de Walle 2011). It is safe to assume that such tasks are already part of their duties before the men leave the workload simply increases. 


\section{Forest resources in Tajikistan}

During the Soviet era, forests in Tajikistan were managed according to cyclical plans that sought to protect timber stocks. A national inventory of forests was conducted across most of Tajikistan during the 1970s and 1980s, on the basis of forestry management principles (lesouztroistvo). These plans set the baseline for the entire forestry sector using detailed mapping and copious reports from local monitoring stations. Forest-management schemes promoted sustainability through mechanization and simplification of forest zones. Subsequently, nearly all forests were maintained under a protected status in rural Tajikistan and were to be expanded through the constant iteration of 5-year plans. Given arid and rocky conditions, these plans were rarely met in Tajikistan (Padalko 1980). Following independence in 1991, such thorough, albeit unrealistic, planning efforts ceased to exist in Tajikistan.

Degradation and destruction of Tajikistan's remaining forests started immediately after independence, and accelerated during the civil war from 1992 to 1997 (Kirchhoff and Fabian 2010). As state supports for coal, oil and gas disappeared, residents turned to locally sourced firewood for their heating and cooking. Illegal cutting, conversion to agricultural land, wood harvesting for fuel and overgrazing by livestock were the main drivers of deforestation in the country (Kirchhoff and Fabian 2010, 24). Firewood continues to be a critical energy source for rural households. State institutions that should ostensibly be in charge of protection rarely achieve even basic supervision over forest zones, and have at times been responsible for their loss. In the absence of government capacity, a long-awaited process of land tenure reform has set the stage for households to take ownership over their own territories and extend their impact on resource management more broadly.

\subsection{History of Tajik forestry}

Prior to the Soviet era, forest stocks had been a concern for those administering Tajikistan's territory, primarily because trees were in such short supply. Work on erosion and afforestation began in the 1880s, when parts of the region were conquered by the Russian Imperial Army (Yusupov 1966). The first research entity dealing with forest management in Central Asia was established in 1927: the Central Asian Forest Research Station (SATsLOS). ${ }^{9}$ By 1948 it had become the Central Asian Research Institute of Forestry [SredazNIILH (СредазNИИЛХ)]. For the most part, forestry policy was uniform across Central Asia, dispensed from the SredazNIILH to the associated research stations and institutes throughout the republics, which in turn set the parameters for the State Forestry Enterprises (Leskhoz) and other ecological resource managers.

To enhance the study of erosion effects in mountainous regions, the Chatkalskay MountainAmelioration Experimental Station was established outside Uzbekistan's capital city of Tashkent and another in Varzob, a gorge just north of Dushanbe, the capital of Tajikistan. These centers developed experimental plots on terraces to determine ideal mechanized growing methods and to study the growing conditions and forest properties that would encourage the most productive forests (Kocherga 1966, 18). These research centers also organized "major complex research expeditions to mountain territories in all the republics of Central Asia [involving] specialists from various branches of knowledge: hydrologists, soil scientists, foresters, forest ameliorators, agronomists, hydrotechnicians, mechanizers and economists" (Kocherga 1966, 19).

9 SATsLOS was then reorganized in 1934 and placed under the control of the Uzbek Soviet Socialist Republic. Shortly thereafter, the Uzbek Institute for Forestry was created in Tashkent in 1936. 
This multifaceted approach led to policies focused on afforestation of mountain slopes, growing tree borders along irrigated fields (particularly in desert regions), and greening city boulevards, leisure parks and health resorts (Yusupov 1966). As a whole, the emphasis was on meeting annual and 5-year quotas, which dictated the number of hectares to be planted in order to combat erosion, protect against landslides, maintain the water table and improve air quality.

With access to a nearly limitless supply of Siberian timber for construction and industry, Central Asia was always understood to be a net importer of forest products. However, from the outset, Soviet foresters and planners recognized the many benefits of forest protection, citing a need to wage a 'battle for afforestation' (Nigmatov 1977). In the mountain regions, the study of afforestation and its practical application were primarily focused on mechanized planting on terraced steps of pine trees and fruit orchards. Such an endeavor meant that monocrop forests would typically be grown to enable mechanization to the greatest extent possible. Although a great deal of Central Asia's territory is low-lying desert and steppe, the Tian Shan mountains in Kazakhstan and Kyrgyzstan and the Pamir-Alai mountain ranges across Tajikistan and Kyrgyzstan provide ample mountain terrain. While Central Asian urban plantings and narrow tree bands alongside fields have held up well, most mountain forest plots failed planned targets (Fleming 2014).

For all of its inefficiencies and missteps, the Soviet forestry complex was well-funded, held adequate technical resources and maintained useful maps of its territories and species distribution. These assets were basically left in place when the Soviet Union collapsed. No systematic mapping of Tajik forests has been undertaken since 1991 and most maps held by state agencies date from the 1980s or earlier. The vehicles and mechanical equipment date from that era as well, meaning that they are mostly rusted and beyond repair. The irrigation systems, trenches, plantations and maintenance roads that you find today were likely put in place by the last Soviet-paid foresters. These resources continue to be actively maintained by local users and Tajikistan's state agencies, whenever (typically external) funding makes it possible. As in most post-Soviet institutions, the most valuable resources and equipment were sold off by self-serving management or left in disrepair.
In Tajikistan, owing to the calamitous civil war, forest resources faced particularly severe predation as the state was unable to provide heating and electricity for many years. Most forestry experts left their posts to emigrate to Russia or found work in other sectors, leaving the state with limited oversight and almost no money for afforestation, planning or conservation.

\subsection{State of the forests}

Forests make up only $3 \%(421,800 \mathrm{ha})$ of Tajikistan's total land area (14.31 million ha) (TAJSTAT 2015c). Of these, the majority consist of juniper pine forest $(150,000 \mathrm{ha})$, pistachio plantations (78,000 ha) and shrubs (58,400 ha) (TAJSTAT 2015c, 30). The state also deems $100 \%$ of the forests to be under protection and that 320,000 ha $(76 \%)$ are untouched by human activity [Леса, не затронутные деятельностью человека] (TAJSTAT 2015c, 32). It is likely that forests comprise even less than that indicated by government statistics. Recent satellite imagery assessments have found that forest cover percentage constitutes only $1.05 \%$ of the land in Tajikistan (personal communication from C. Martius, 2016).

During the Soviet period, the territory of the State Forest Fund (GosLesFond) consisted of 1.7 million ha, of which usable forests constituted only 106,000 ha (Vihrestok and Padalko 1983, 26). Out of this large area, 1.2 million ha were in longterm leases to collectivized and state-run farms, that, in turn, could only make use of $1.2 \%$ of this area productively (Vihrestok and Padalko 1983). In the post-Soviet era, the State Forestry Agency now manages 1.8 million ha - claiming to afforest 55,000 ha of territory annually while losing 1500 ha to felling (TAJSTAT 2015c). Due to numerous Soviet land swaps, there are still irregularities regarding which land actually belonged to collective farms and should be privatized, versus public land that would continue to be held under State Forestry Agency control. Regardless, most of the existing stands of forests are sparse and fragmented (Wölcke et al. 2013). Across the country, thin juniper forests are evident in alpine and subalpine zones. Visual evidence suggests that far denser and more heavily used forests are usually found surrounding village habitations and along creek and river banks. Nearly all Tajik rural areas are surrounded by and interspersed with trees, thereby making human settlements the main determinant of forest cover. 


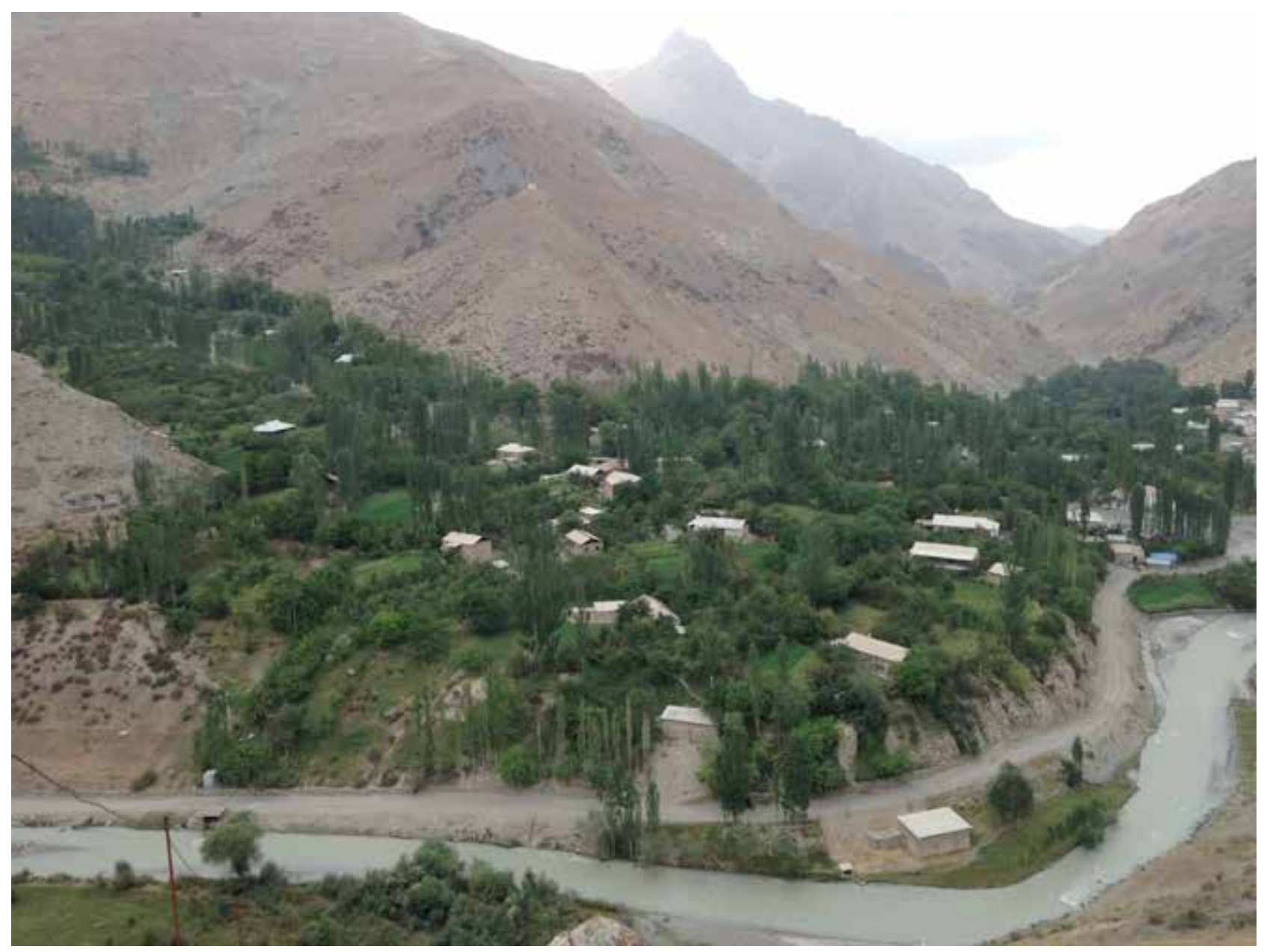

Typical mountainside village surrounded by orchards and woodlands above the banks of the Zimtud river. (Photo taken by the author)

Local residents have taken on a greater role in ecological management as they witness the Tajik government failing to meet its official obligations. The Committee for Environmental Protection (CEP) was established in Tajikistan in 2008 to regulate the use of natural resources and ensure their protection. During the Soviet era, this task had been distributed among several ministries and departments, such as the Ministry of Water Melioration, the Ministry of Agriculture, the Ministry of Health, the State Forest Authority, the Administration on Geology and the Committee on Industry. The CEP has struggled to reach basic funding levels and has extremely limited authority if infractions are found. While there is a comprehensive listing of environmental fines and valuations of forest products, this information is not available to the public nor are there CEP officials in rural areas to enforce them.
A new Forestry Code was instituted in 2011, revamping the institutional structure of the forestry sector, including the CEP. The code stipulates that all forests in Tajikistan are part of a Unified Forest Fund consisting of the State Forest Fund, which are territories administered by state agencies, and the Public Forest Fund, controlled by individual farms, cooperatives and commercial enterprises. The State Forest Agency is the governmental body coordinating forestry policy on the national level in Tajikistan. The agency oversees 41 state forest enterprises (Leskhozes) and five forest reserves (zapovedniki) to manage State Forest Fund land, while the Forest Inspection Service ensures proper oversight. Carrying over from the Soviet system, the key institution in Tajikistan's forestry sector interacting with local populations is the Leskhoz (State Forestry Enterprise), which has field offices in every oblast (region) of the country and also maintains 
a presence at the rayon (district) level. Their task is to manage, protect and improve the State Forest Fund and assist all other entities in their efforts on the public's land. The CEP sets guidelines that severely limit maintenance cutting and felling of any kind. The leskhozes nonetheless operate as entrepreneurs that sell forest products to other government entities (such as local schools and police bureaus) and to local residents directly. As a result, there is significant confusion regarding leskhoz priorities and practices. Hopefully, a strategic plan for 2016-30 will help define how the state will manage Tajikistan's forestry sector and support private actors as synergistic partners in their efforts.

On the whole, Tajikistan has limited forest cover. However, there are significant tree stands, particularly surrounding rural settlements. These orchards, woodlots, shrubby pastures and riparian boundary zones are the most intensively managed forests in the country. It is therefore more useful to think of forests in Tajikistan as extensions of socioecological systems rather than distinct ecological resources separate from the population. There are scarcely any forests that have not been improved or degraded by human and livestock use in the country. Thus, a more holistic and use-oriented view of sylvan resources is recommended.

\subsection{Land reform}

While the Tajik Government continues to clarify the role of its institutions and improve their capabilities, it has enacted a series of land reforms that have provided citizens with greater control over land. Since 1997, land has haltingly been decollectivized. Although the state still legally owns all the land, $82 \%$ of this is now farmed by 108,035 privately owned dekhan (peasant) farms (Lemon 2016). "The essence of land reform in Tajikistan is therefore reallocation of state-owned agricultural land among producers through the mechanism of land use rights" (Lerman and Sedik 2009, 305). Technically, land is not in private hands but use rights for land can be transferred to dekhan farms or a group of farmers.

Land restructuring policies were slow to start but have been pushed more aggressively since 2007, such that state and collective farms account for less than 19\% of all arable land (Theesfeld and Klümper 2016). In March 2016, a new law on dekhan farms assured their status as legal entities and gave farmers the right to build temporary structures on their land. From a legal and practical point of view, farmers and landholders in Tajikistan have begun to view the land as their own, even if they are not its owners outright.

Despite steady progress in land reform, problems with governance and corruption persist, particularly in cotton-growing regions where access to irrigation is more centrally controlled. In such zones, dekhan farms have remained nominally private and can still seem as though they are managed collectively (USAID 2010). ${ }^{10}$ However, in mountain regions, collective farms have historically held less productive territories and focused their efforts on livestock grazing, tobacco or other industries that are not amenable to elite resource capture. In rural areas, typical homestead areas are mixed with orchards and vegetable gardens, including stands of poplar trees. Fields and plots vary considerably in size, but rarely exceed 300-400 $\mathrm{m}^{2}$ (Heergarten 2004). Thus, they are difficult to oversee through centralized efforts and irrigation is typically distributed through a series of aryks (water channels) ${ }^{11}$ that are maintained by a combination of collective action, individual initiative or, more recently, water user associations.

Rather than facing pressure to meet collective farm quotas, mountainous rural households are essentially left to their own devices. They find opportunities for collective collaboration amongst neighbors, extended household members and friends during times of heightened activity (such as when repairing a canal or bringing in a harvest). Neighbors and family can rely on each other, and often have to, with so many men circulating outside the region and the country for work. While these support networks are crucial, the structural factors outlined above exacerbate the limited resources of rural households to

10 Furthermore, women-headed households have struggled to receive land transfers and are typically allotted less arable land (USAID 2010).

11 These water channels usually flow from small rivers that are fed by glaciers atop adjacent mountains during the hot summer months when rainfall is minimal in Tajikistan. The glacier reservoirs are in steep decline and face significant warming pressure from global climate change - one of the most pressing issues for Tajik ecology and agriculture, particularly for individual farmers (Tajik Meteorology 2007; Oxfam 2009). 
fundamentally improve their conditions. There are simply too many fundamental rural infrastructures that had been built and maintained by Soviet collective farms which have now either been abandoned or 'privatized' by local power brokers. Most rural farmers in the mountainous regions of Tajikistan no longer have regular access to tractors or other technical machinery (having to lease them at great expense from local owners, if any are functioning). They are left to farm with oxen ploughs and human labor. As the government's role in resource management remains limited and under-funded, residents have to figure out how to make the most of the land that has been entrusted to them. They must account for the absence of farm equipment and family members to subsist and try to turn a profit. Improved land tenure has encouraged many to consider trees and woodlands as valuable and desirable resource strategies. 


\section{Rooting mobility through forests}

What factors will influence Tajikistan's ecology in the era of migration? Given the enormous importance of migrant remittances outlined in the sections above, and the uncertainty in the literature regarding their effects on forest and ecological resources, what will Tajikistan's fragile ecological landscape look like? Given a similarly tenuous baseline of infrastructure, expertise and management in post-Soviet Central Asia as a whole, can Tajikistan follow its own resource management path? The country has several characteristics that make it unique among postSoviet Central Asian countries. A relatively recent stabilization of land tenure has provided a significant boon to natural resource management at the household level. While the government is still technically the rights holder to all land in the country, it has agreed to very long-term tenant agreements, giving residents the security to invest for the future (Lerman and Sedik 2009). After seven decades of collectivized land policies followed by two decades of war and legal limbo, people are more confident in making long-term investments in their land.

The current political, ecological and infrastructural conditions in Tajikistan have presented limited opportunities for rural households. Family-run rural farms are the bulwarks of the nonmigrant economy. With jobs extremely scarce outside of the public sector, and even those few providing little succor, ${ }^{12}$ the potential to generate income from privatized land holdings offers a buoy in tumultuous economic times. In recent years,

12 Rural salaries for government employees are low. Teachers, for example, earn roughly USD 50 per month. Pensions are in the range of USD 40-100 per month. The average annual per capita GDP in Tajikistan was USD 1150 in 2015 (World Bank 2016) - including remittances. While extreme poverty has fallen in the country (defined by the World Bank as less than USD 1.50/day), thanks largely to remittances, over three-fourths of the country is still below the poverty line (TAJSTAT 2015b). households have invested in a resurgence in fruit tree cultivation to overcome economic hardship (for similar conclusions from Kyrgyzstan, see Carter et al. 2003). These rooting strategies are occurring alongside, and with the support of, migration. Ethnographic research conducted by the author offers numerous examples. For instance, in Vanj Valley in the Pamir mountains, a father traveled to Russia a decade ago, earning enough money to purchase a car and make improvements to the household's agricultural fields, but not enough to purchase farm machinery. His son was working abroad, helping to support the family while the agricultural fields transitioned to tree crops. Alongside the orchard, the father carefully tended a woodlot for firewood and timber removal through sustainable thinning. As the migrant son circulated back home, eventually planning to stay, he would work on the orchards and forest lands that his father had established for the future. The household's key long-term investments were trees. Further research is needed to understand how an emphasis on horticulture and silviculture is affecting forest resources nationally and at the local level.

While annual crops (such as cotton, potatoes, wheat and vegetables) continue to play an important role in rural livelihoods, fruit orchards are emerging as an important way to capitalize on land stability. Part of the difficulty in assessing forest changes is that the Land Cadastre Agency and the tax authorities have sought to curtail the conversion of fields, pastures or fallow terrain into forests or orchards. Nonetheless, government institutions, such as the Leskhoz, are beginning to see local users as a benefit to their resource management strategies, rather than a threat. As a result, local populations are able to improve and expand forest resources - both through individual initiatives and collaborative efforts involving state actors - such as Joint Forestry Management schemes. This is but one example of a larger interest in forestry and tree cultivation that is emerging as Tajik citizens plan for their long-term economic and ecological future. 
At the same time, grave challenges remain. Extension services and domestic research institutes are unable to provide assistance. Local Tajik workers were trained for jobs other than the small-holder horticulture and agriculture that they have increasingly relied upon since the collapse of the Soviet state. Thus, there is a significant knowledge gap that stands to be addressed by international, state and local institutions to support forest management. This would require educational or outreach services to assist households directly, coupled with broader land management coordination to support and improve their efforts. Roads, irrigation canals and heavy equipment are well past their intended life spans and there are very few funds for their replacement. Nearly all cultivation and forestry efforts in mountainous areas are dependent on manual labor, occasionally with the aid of donkeys and perhaps a few lumbering Soviet-era vehicles. For a viable forest stabilization and resurgence, not only will the efforts of local people need to be supported, but their individuated responses will have to be coordinated to overcome vulnerabilities.

\subsection{Contemporary forest dynamics}

There are debates in the natural resource management literature over whether migrants are a positive or negative force for forest growth. How forests and agroforestry systems are managed depends on different migratory and ecological contexts. Forests play a prominent role in the literature on adaptation to climate change and mitigation efforts, especially in studies focused on reducing emissions from deforestation and forest degradation. These discussions, however, rarely consider migration to be a positive factor, often assuming that deforestation is a direct outcome of immigration. Meanwhile, rural development efforts seek to discourage outmigration based on the logic that it compromises ecological sustainability. There are dissenting opinions on both counts.

How migration affects forest dependence is still poorly understood. Studies suggest that migration can both increase and decrease peoples' engagement with forested landscapes depending on context (Kosek 2006; Mathews 2011). The relative scarcity of data and analysis of the connections between migration, remittances and forest use reflects a dismissal of forests as a cornerstone of many rural/urban livelihoods. "The forest question is either subsumed in the formal literature under 'agricultural' or 'rural' without differentiation, or it is ignored" (Hecht et al. 2015, 24). Much existing literature linking forests and migration remains premised on overly simplistic assumptions. It is either argued that tropical deforestation is an effect of migration into forests (Carr 2009), or that outward migration alongside land use substitutions improve forest cover (Mather 2007). Rural areas also have to be recognized as maintaining deep connections with urban and globalized market processes. Any field site or pilot area, no matter how 'out of the way' (Tsing 2004), is necessarily connected to mobile forms of governance (Gupta and Ferguson 2002), political and social movements (Escobar 2014) and the insistent penetration of capital (Harvey 1982). Such interconnectivity demands a more nuanced view of humanecological interactions.

Under the 'new economics of labor migration,' smallholder farmers use remittances to invest in land in order to intensify agricultural use or to transition to cattle ranching (Davis and Lopez-Carr 2014). This theory suggests that forest resources would be harmed by the entrepreneurial logics of remittances. Not all migrant-sending contexts offer the same cost-benefit scenarios. The use of remittances to intensify agriculture production may or may not have negative implications for forests, depending on existing contexts and the availability of alternative livelihood strategies (Gray and Bilsborrow 2014). While there may be an initial loss of the household's available labor supply when the migrants first leave, examples show that remittance flows enable investment into agricultural inputs to make up for those who are absent (de Haas 2007). In some rural areas, the receipt of remittances has led to agricultural withdrawal, which has initiated forest resurgences (Aide and Grau 2004). On the other hand, Gray and Bilsborrow (2014) show that outmigration allowed for an expansion of cultivated areas at the household and community scales in rural Ecuador. Thus, there is contradictory evidence outlining how migrant-sending regions deal with natural resources.

It has been assumed that "migration generally improves the living standards of migrants and leads to the disintensification of land use in fragile ecosystems with low productivity" (Grau and Aide 2007, 119). However, in the highlands of Mexico, agricultural abandonment and forest regeneration are found alongside forest degradation, 
as a result of woodcutting (Klooster 2003). Even reforestation itself can accompany declining forest quality wherein soils are depleted and genetic variety diminished (Klooster 2003, 233). Thus, it is possible that even in a given site, some forests may benefit from migration while neighboring territories suffer.

One means of disaggregating these effects is proximity to roadways. In the Ecuadorian rainforest, distant lands were abandoned and regrew organically, as non-farm incomes supplemented and then replaced the need to use the sites (Rudel et al. 2002). Even as non-agricultural sources of income influence land use, smallholders in developing countries adaptively manage their land, reforesting for long-term streams of income or cutting into it when short-term gains or alternative uses were more desirable. Research by the author suggests that, while the gathering of firewood and excessive livestock grazing continue to put pressure on alpine forest stands in Tajikistan, riparian and low-lying areas seem to be expanding in response to migratory circulation and land tenure reform. Part of the expansion in forest stocks can be attributed to fruit and nut trees.

\subsection{Tree cultivation}

The cultivation of fruit trees has been a historically long-standing practice in Central Asia - the genetic progenitor of the modern apple can be found in the Altai mountains of Kazakhstan - and the region is a rich center of genetic diversity of fruits and nuts (Lapeña et al. 2014). Fruit trees are common, with crops including apricots, peaches, apples, mulberries, sea-buckthorn (for medicine and juice), cherries, grapes, pears and plums. In autumn, a variety of locally grown nuts are also available, such as walnuts, pistachios and almonds. Fruits are often dried or minimally processed for storage so that they can be consumed during winter, supplying important vitamins and adding considerable nutritional value to the normal food staples (consisting primarily of wheat, potatoes and rice). Export of dried apricots to Russia is another important driver of orchard intensification, particularly in Sughd and Khatlon oblasts. However, processing facilities are underdeveloped or nonexistent in Tajikistan. For this reason, tree crops that can be sold and transported without processing have become more popular - particularly apples, pears and walnuts.
During the Soviet period, when growing crops of choice outside one's own very small kitchen garden was forbidden (Rowe 2009), few fruit trees survived in the fields of local residents. Nowadays, fruit trees are usually planted in garden plots adjacent to homes. Orchards are also increasingly encroaching on productive agricultural land that had been converted from other uses. ${ }^{13}$ Local nurseries in districts around the country often have native and international varieties for grafting. Commercially viable varieties that can keep throughout the winter months in order to be sold later in the year are growing in popularity. Smallholders are interested in planting more fruit trees to diversify livelihood strategies, for example, on leskhoz land (Kirchhoff and Fabian 2010). In Sughd, the wealthiest and northernmost region, and in the district around the capital, Dushanbe, commercial enterprises have begun to resurrect large-scale Soviet plantations and capitalize on emerging market opportunities. Outside of these more densely populated areas, in the mountain valleys that characterize most of Tajikistan's territory, smallholders prevail. They are surrounded by trees planted during the Soviet period. Many of these plantation orchards still stand but are overgrown or produce poor yields. To return to productivity, these territories would require a concerted effort from local populations living adjacent to them. With the leskhozes and other state agencies limited in personnel and funding, a resurgence in fruit tree cultivation has been taken up by local residents.

\subsection{Nutritional effects}

Malnutrition is a serious concern in Tajikistan. Child malnutrition is among the highest in the CIS region, with levels of those with stunted growth reaching 34\% (Azzarri and Zezza 2011, 54). According to recent estimates, $15 \%$ of children are underweight (severely or moderately) and 7\% exhibit wasting (severely or moderately) (UNICEF 2014). Apart from facing caloric and nutritional deficiencies, children in Tajikistan are frequently

13 While the Tajik Land Cadastre Agency technically requires permission to alter the status of land from agriculture to orchard, for instance, many people make the changes without receiving all the necessary paperwork. Given the absence of up-to-date mapping in the country, it is unlikely that such changes in land use can be tracked accurately. 


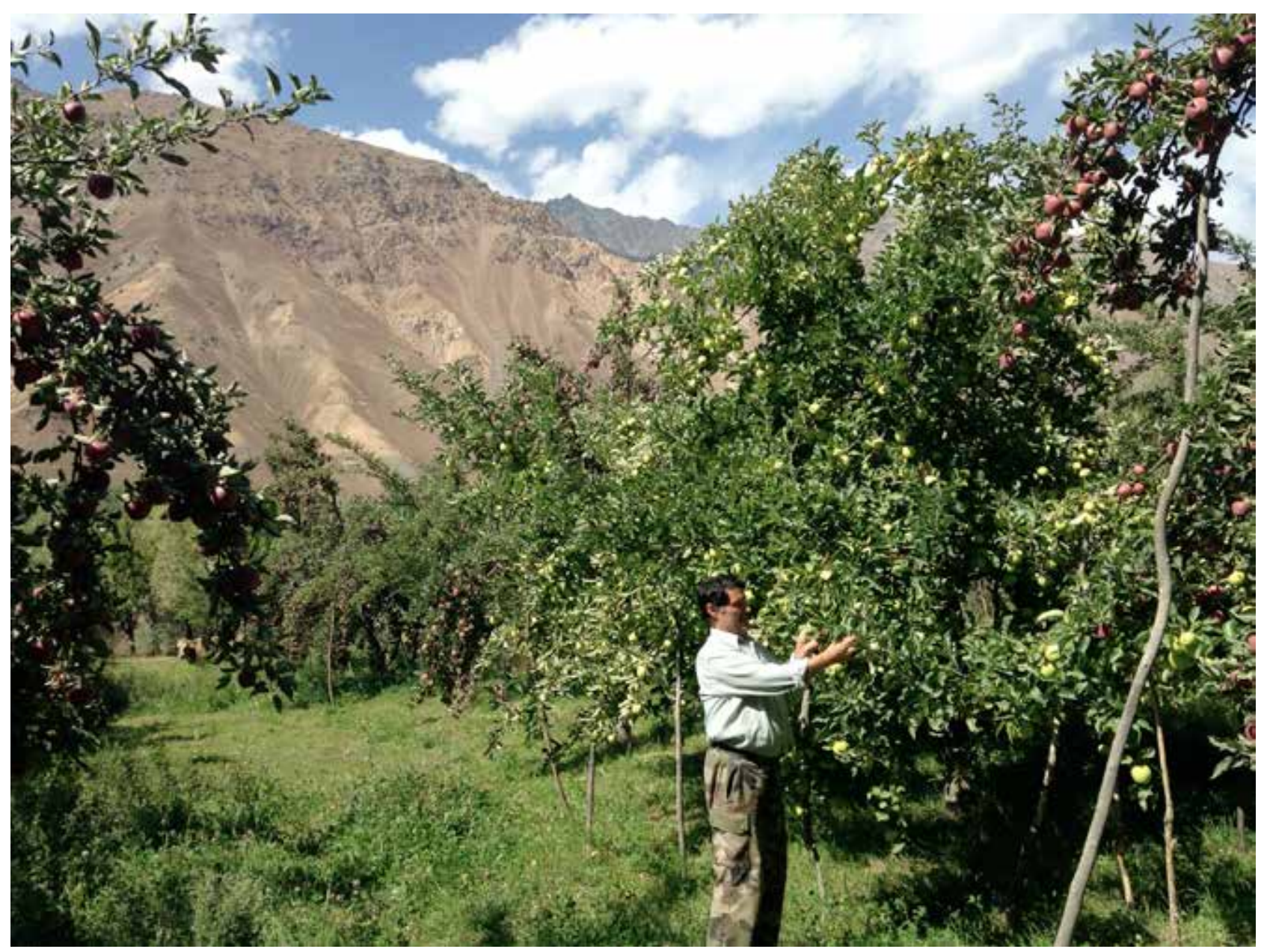

Apples ready for harvest in Vanj Valley. (Photo taken by the author)

called upon to work. ${ }^{14}$ Most commonly, children work at the same time as they attend school and complete domestic chores. A great deal of their labor consists of farm work alongside their families in or around their homes, such that $83 \%$ of working children are involved in agriculture, especially during the summer months (ILO and IPEC 2015, vi). Thus, Tajik children have to work to help their families produce food, while lacking the nutrients they need to grow.

However, migration is affecting household consumption. Increased kilocalorie intakes suggest that "children in both household and communities with greater access to migration enjoy better nutritional status than other Tajik

14 The highest employment rate is observed among 15-17-year-old boys at $45.5 \%$. Even among the youngest age group (5-11-year-olds), the employment prevalence is quite high at $10.7 \%$ (ILO and IPEC 2015, v). children" (Azzarri and Zezza 2011, 66). One way that necessary goods are made available to households whose children are facing privation is material remittances. While migrants send important (though unreliable) remittances through wire transfer services, a far less traceable, but important, form of mobile circulation involves material remittances. These are particularly important and common in multilocal settings where some household members live in urban areas (without access to farming land or livestock products) while their relatives live in rural areas.

Largely unrecorded, in-kind remittances can have important impacts on local economies as well as on household well-being (Ellis 1998; Taylor 1999). In-kind remittances serve as an "important redistributive mechanism for food across space," helping to reallocate resources during hardship or make up for crop failures (Andersson 2011). 
When a family deems it necessary to send potatoes to their city-dwelling daughter struggling through the winter, or when an ill pensioner wants to send a box of walnuts to his doctor to make sure that the medication is available the next time he arrives at the hospital, the flows of goods and the circulation of people become intertwined. Few reliable datasets exist on the size of internal remittances, and thus their importance in poverty reduction may be underestimated (Esipova et al. 2012). Smallholder farmers may have substantial responsibilities for producing food for urban and multilocal networks, but these are hard to determine without careful ethnographic analysis.

\subsection{Social remittances and forest resurgence}

Beyond meeting nutritional needs and providing economic flows, migration also produces social remittances. Social remittances are "ideas, behaviors, identities and social capital that flow from receiving to sending country communities" and vice versa (Levitt 1998, 929). Migrants are not only able to share money and material goods, but also ways of improving livelihoods that may not have been in practice in sending communities. While financial investment may help to introduce new technologies and capabilities, mindsets and practices can also be put to use. For many young Tajik men, migration is a rite of passage that also connects them to migrant networks abroad and encourages the circulation of evolving cultural trends (Rankin 2006). These evolving notions of proper work can prove consequential for migrants who return to their rural homesteads. "Social remittance flows may move from urban to rural places and can affect relationships of migrants and others with land and forest resources" (Hecht et al. 2015, 24). Ideas acquired in the course of migration can alter perceptions of the environment and how it is used. In Malaysia, for instance, migrant experiences encouraged a shift away from traditional smallholder practices to engagement with monocultural plantations (Montefrio et al. 2014). More research is needed to fully understand the ideas Tajik migrants and their households hold toward forest resources. Nonetheless, some dynamics can be determined.

Part of the underpinnings of multilocal mobility is a reluctance on the part of some migrants to want to return to rural communities. Many migrants accustomed to cosmopolitan urban centers may chafe under the limitations of rural life. Therefore, it is conceivable that rural activities would become devalued by migrants, leading to agricultural abandonment (Radel and Schmook 2010). However, in Tajikistan, where population growth is still the highest in the former Soviet Union, there are usually multiple sons in a household willing (or needing) to take over territories from older generations. Thus, even if one or more sons are interested in returning to urban areas after working abroad, there are typically other family members who are able to make use of lands - who may or may not have also been migrants themselves. The ecological and material conditions of the household are an important incentive to encourage migrants to settle back home. As a result, an abandonment of agricultural lands has not been observed in Tajikistan (except for arid territories that had been watered by large-scale Soviet irrigation works that no longer function).

It is likely that one of the significant effects of this evolution in migrant mobility and land use strategies is an increased interest in forests and tree crops. The author's ongoing research suggests that some return migrants may be inclined to take neglected lands, underproducing leskhoz plantations, or even productive agricultural territories and convert them into forested zones for firewood and construction materials and/or orchards. This continued engagement with rural areas ensures that migration and forest use in Tajikistan are interrelated, whether through the circulation of ideas and income to migrant-sending families or by the return of migrants to agriculturally productive homesteads. Very few households in Tajikistan are able to separate themselves from subsistence and agricultural labor, no matter their success abroad. While the country had once been on a path to modernization and industrialization, it has reverted to an agriculture-dominated rural peasantry that sends out labor migrants who, for the most part, return to work the land.

As part of broader transformations of land use, the dynamics of forest resurgence are determined by changes in access and control (Agrawal and Benson 2011). Property rights and legal regimes are not enforced evenly throughout 
Tajikistan and access to markets is variable. Some leskhoz offices are eager to collaborate with local smallholders to expand forest zones, while others are wary of losing control of state lands. The interaction of the Tajik state and its citizens will help determine how the effects of migration influence the landscape. This constellation of factors will continue to shape Tajik forestry and land use for years to come and deserves critical policy and academic attention. 


\section{Conclusion}

Migration is a fundamental part of life in postindependence Tajikistan. As the world's most remittance-dependent economy, social, political and ecological activities are deeply bound up with people's propensity to move. The challenges brought about by a weak state and economic instability have induced the population to take on migration alongside small-scale agricultural production. Attention must be trained on the role of mobility in all sectors of Tajik society, including, as this paper suggests, on the ways in which migrants' remittances affect forests and tree crops. Out of transnational, circular, gendered, multilocal and (il)licit flows emerge tensions and risks, as well as opportunities. Changes to Tajikistan's land tenure regime and the semblance of stability after a lost decade of war and upheaval have breathed new life into long-term ecological management, offering sylvan regeneration as a potentially promising livelihood strategy.

Migration is not a one-dimensional force with clearly defined outcomes. Forest zones are not necessarily bereft of activity when migrants depart. Nor does emigration inevitably lead to forest resurgence, as lower population densities in forest areas can lead to increased deforestation because of diminished oversight and new forest uses. Research and policy must be attuned to "the range of drivers that might affect the volume, direction, and frequency of migratory movements, on one hand, as well as the different levels of analysis at which migration might be considered as influencing forest change, on the other" (Black et al. 2011, 5). More visible forms of intensification of agricultural production, such as irrigation, and machinery and agricultural inputs, are easier to document than more subtle landscape modifications and adaptive woodland management (Brondizio 2004). A multidimensional approach that includes environmental, social, political, demographic and economic factors is essential
(Hecht et al. 2015, 13). Close analysis of environmental and human factors indicates that they have to be considered as mutually constitutive interactions. Only then will the forest and the trees come into view.

Tajikistan offers a unique and interesting case study for several reasons: (a) Tajikistan is an arid, high-mountain country that benefits from people's commitment to forest resurgence, rather than the absence of human involvement; (b) migration is highly circular, with many migrants returning each year owing to the laxity of the visa-free regime (alongside onerous restrictions on labor and residency permits); and (c) a majority of Tajik migrants eventually plan to return home and hope to establish a stable income source. Since the business and investment climate is extremely unstable with endemic corruption, elite capture and exorbitant interest rates on loans, migrants are unlikely to invest outside of their immediate sphere of acquaintances, assets and networks. For many, the best bet is investing in their own household and its adjoining territories.

In order to succeed, migrants and their family members would benefit from agricultural extension services, favorable lending mechanisms and further training in agriculture, horticulture and silviculture techniques. As rural Tajikistan continues to rely on agrarian labor as a counterweight to migration, its citizens would benefit from hands-on and practical guidance in managing the land in which they are invested.

Fortunately, the land tenure regime has stabilized in Tajikistan over the last decade such that agriculture and forestry have emerged as particularly reliable income sources. The interest in forests in general, and orchards in particular, offers a promising opportunity for the migrationdependent Tajik economy. Facing largely 
ineffective and underfunded state institutions, local residents are the crucial determinants of forest cover in an arid region. Without their efforts in irrigation, planting and limiting livestock grazing, existing forests would deteriorate and new forests could not take root. At the same time, there are still vast mountainsides devoid of forest cover, overtaxed grazing lands and inefficient irrigation systems. Migrants will continue to return to these territories to shape what grows there. Scholars, government and nongovernmental actors interested in Tajikistan's well-being should pay close attention to these socio-ecological developments and aid them as much as possible. 


\section{References}

Agrawal A and Benson CS. 2011. Common property theory and resource governance institutions: strengthening explanations of multiple outcomes. Environmental Conservation 38(2):199-210.

Aide TM and Grau HR. 2004. Globalization, migration, and Latin American ecosystems. Science 305:1915-6.

Akhmadov K. 2005. Global Forest Resources Assessment. Country Reports: Tajikistan. Rome: Food and Agriculture Organization of the United Nations (FAO).

Akhmadov K. 2008. Geneva Timber and Forest Discussion Paper 46. Forest and Forest Products Country Profile: Tajikistan. New York: United Nations.

Andersson A. 2011. Maize remittances, smallholder livelihoods and maize consumption in Malawi. The Journal of Modern African Studies 49(1):1-25.

Azzarri $C$ and Zezza A. 2011. International migration and nutritional outcomes in Tajikistan. Food Policy 36(1):54-70.

Bebbington AJ. 1999. Capitals and capabilities: a framework for analyzing peasant viability, rural livelihoods and poverty. World Development 27:2021-44.

Bebbington AJ. 2000. Re-encountering development: livelihood transitions and place transformations in the Andes. Annals of the Association of American Geographers 90:495-520.

Black R, Adger WN, Arnell NW, Dercon S, Geddes A and Thomas D. 2011. The effect of environmental change on human migration. Global Environmental Change 21:3-11.

Boyko A. 2015. "Мигранты переустраивают под себя столицу”, Komsomol'skaya Pravda, 20 July 2015. Accessed 19 June 2016. http://www. msk.kp.ru/daily/26407.7/3283172/

Brondizio ES. 2008. The Amazon Caboclo and the Açai Palm: Forest Farmers in the Global Market. Bronx, NY: New York Botanical Garden.
Cabrera AR, Deadman PJ, Moran E, Brondízio ES and Vanwey LK. 2012. Exploring demographic and lot effects in an ABM/LUCC of agriculture in the Brazilian Amazon. In Heppenstall A, Crooks A, See LM, and Batty M, eds. AgentBased Models of Geographical Systems. Berlin: Springer. 663-76.

Carr D. 2009. Rural migration: The driving force behind tropical deforestation on the settlement frontier. Progress in Human Geography 33(3):355-78.

Carter J, Steenhof B, Haldimann E and Akenshaev N. 2003. Collaborative Forest Management in Kyrgyzstan: Moving from Top-Down to Bottom-Up Decision Making. Gatekeeper Series 108. London: International Institute for Environment and Development (IIED).

Cassarino J-P. 2008. Return Migrants to the Maghreb Countries: Reintegration and Development Challenges. San Domenico di Fiesole: European University Institute.

Chambers R and Conway G. 1992. Sustainable Rural Livelihoods: Practical Concepts for the 21st Century. Brighton: Institute of Development Studies.

Chang H, Dong X and MacPhail F. 2011. Labor migration and time use patterns of the leftbehind children and elderly in rural China. World Development 39(12):2199-210.

Chant S. 1998. Households, gender and ruralurban migration: reflections on linkages and considerations for policy. Environment and Urbanization 10(1):5-22.

Conrad C, Lamers JPA, Ibragimov N, Löw F and Martius C. 2016. Analysing irrigated crop rotation patterns in arid Uzbekistan by the means of remote sensing: A case study on postSoviet agricultural land use. Journal of Arid Environments 124:150-159.

Davis J and Lopez-Carr D. 2014. Migration, remittances and smallholder decision-making: implications for land use and livelihood change in Central America. Land Use Policy 36:319-29. 
de Haas H. 2012. The migration and development pendulum: A critical view on research and policy. International Migration 50(3):8-25.

de Haas H. 2005. International migration, remittances and development: myths and facts. Third World Quarterly 26(8):1269-84.

Esipova N, Pugliese A and Ray J. 2012. The Demographics of Global Internal Migration. Geneva: International Organization for Migration (IOM).

Ellis F. 1998. Household strategies and rural livelihood diversification. The Journal of Development Studies 35(1):1-38.

Fleming J. 2014. Political ecology and the geography of Science: Lesosady, Lysenkoism, and Soviet science in Kyrgyzstan's walnut-fruit forest. Annals of the Association of American Geographers 104(6):1183-98.

Kuvatova A. 2014. Review "Women and Farming" (Gender Analysis in Agriculture of Republic of Tajikistan). Dushanbe: Youth Ecological Centre.

Ge J, Resurreccion BP and Elmhirst R. 2011. Return migration and the reiteration of gender norms in water management politics: Insights from a Chinese village. Geoforum 42(2):133-42.

Geddes A, Adger WN, Arnell NW, Black R and Thomas DSG. 2012. The implications for governance of migration linked to environmental change: key findings and new research directions. Environment and Planning C-Government and Policy 30:1078-82.

Goldring L. 2001. Gender and geography of citizenship in Mexico-U.S. transnational spaces. Identities 7:501-37.

Government of the Russian Federation. 2014a. Federal Law "On amendments to the Federal Law "On legal status of foreign citizens in the Russian Federation" and separate legislative acts of the Russian Federation". \#357-Ф3.

Government of the Russian Federation. 2014b. Federal Law "On amendments to the article 27" of the Federal Law "On procedures of entry to and exit from the Russian Federation". \#524-Ф3.

Government of the Russian Federation. 2014c. Decree from 18 December 2014, "On identification of the demand for foreign workers, arriving in the Russian Federation on visa, including based on priority professionalqualification groups, and approval of quotas for 2015" \#1400.

Grau HR and Aide TM. 2007. Are rural-urban migration and sustainable development compatible in mountain systems? Mountain Research and Development 27(2):119-23.
Gray CL. 2009. Environment, land, and rural outmigration in the Southern Ecuadorian Andes. World Development 37:457-68.

Gray CL and Bilsborrow RE. 2014. Consequences of out-migration for land use in rural Ecuador. Land Use Policy 36:182-91.

Gupta A and Ferguson J. Beyond "culture": space, identity, and the politics of difference. Cultural Anthropology 7(1):6-23.

Harvey D. 1982. Limits to Capital. New York: Verso.

Hecht S. 2009. The new rurality: forest recovery, peasantries and the paradoxes of landscape. Land Use Policy 17:141-60.

Hecht SB, Morrison K and Padoch C. 2013. The Social Lives of Forests. University of Chicago Press.

Hecht S, Yang AL, Basnett BS, Padoch C and Peluso NL. 2015. People in motion, forests in transition: Trends in migration, urbanization, and remittances and their effects on tropical forests. Occasional Paper 142. Bogor, Indonesia: CIFOR.

Hegland ME. 2010. Tajik male labour migration and women left behind: can they resist gender and generational hierarchies? Anthropology of the Middle East 5(2):16-35.

[ILO and IPEC] International Labour Office and International Programme on the Elimination of Child Labour. 2015. Working children in the Republic of Tajikistan: The results of the child labour survey 2013. Moscow: International Labour Office (ILO), International Programme on the Elimination of Child Labour (IPEC).

[IOM] International Organization for Migration. 2015. Global Migration Trends Factsheet. Berlin: Global Migration Data Analysis Centre of the IOM.

[IOM] International Organization for Migration. 2014. Tajik Migrants with Re-entry Bans to the Russian Federation. Dushanbe: IOM.

[IOM] International Organization for Migration. 2009a. Abandoned Wives of Tajik Labour Migrants. Dushanbe: IOM.

[IOM] International Organization for Migration. 2009b. The effect of the economic crisis on migration tendencies and policies in the Russian Federation, Eastern Europe and Central Asia. [Влияние экономического кризиса на миграционные тенденции и миграционную политику в РоссийскойФедерации и регионе Восточной Европы и ЦентральнойАзии]. Moscow: IOM.

[IOM] International Organization for Migration. 2009c. Economic Dynamics of Labour Migrants' Remittances in Tajikistan. Dushanbe: IOM.

[IOM] International Organization for Migration. 2006. Migration perspectives Eastern Europe and 
Central Asia: Planning and managing labour migration. Vienna: IOM.

Jagger P, Shively G and Arinaitwe A. 2012.

Circular migration, small-scale logging, and household livelihoods in Uganda. Population and Environment 34:235-56.

Justino P and Shemyakina ON. 2012. Remittances and labor supply in post-conflict Tajikistan. IZA Journal of Labor \& Development 1(1):8.

Kasimov M. 1989. Fruit Conveyor of the Golden Valley. [Fruktoviy Konveier Zolotoy Dolini]. Dushanbe: Irfon.

Kanaiaupuni SM. 2000. Reframing the migration question: An analysis of men, women, and gender in Mexico. Social Forces 78:1311-48.

Kelly PF. 2011. Migration, agrarian transition, and rural change in Southeast Asia. Critical Asian Studies 43(4):479-506.

Kirchhoff J-F and Fabian A. 2010. Forestry Sector Analysis of the Republic of Tajikistan. Dushanbe: Deutsche Gesellschaft für Technische Zusammenarbeit (GTZ).

Kireyev A. 2006. The Macroeconomics of Remittances: The Case of Tajikistan. Working Paper 06/02. Washington, DC: International Monetary Fund.

Klooster, D. 2003. Forest transitions in Mexico: Institutions and forests in a globalized countryside. The Professional Geographer 55(2):227-37.

Kroeger A and Meier K. 2011. Labor markets and the financial crisis: evidence from Tajikistan. Discussion Paper 1174. Berlin: German Institute for Economic Research (DIW).

Kocherga FK. 1966. Research work on the fight with erosion of soils and flooding in the mountainous regions of Central Asia. In Proceedings of the Central Asian Research Institute of Forestry Volume X. Tashkent: Uzbekistan Publishers. 16-57.

Kosek J. 2006. Understories: The Political Life of Forests in Northern New Mexico. Durham: Duke University Press.

Lapeña I, Turdieva M, López Noriega I and Ayad WG. 2014. Conservation of Fruit Tree Diversity in Central Asia: Policy Options and Challenges. Rome: Bioversity.

Lemon E. 2016. Nations in Transit: Tajikistan. Washington: Freedom House.

Lerman Z and Sedik D. 2009. Agricultural development and household incomes in Central Asia: A survey of Tajikistan, 20032008. Eurasian Geography and Economics 50(3):301-326.
Levitt P. 1998. Social remittances: Migration driven local-level forms of cultural diffusion. International Migration Review 32(4):926-48.

Mansoor A and Quillin B. 2007. Migration and Remittances: Eastern Europe and the Former Soviet Union. Washington, DC: The World Bank.

Martius C, Rudenko I, Lamers JPA and Vlek PLG, eds. 2012. Cotton, Water, Salts and Soums Economic and Ecological Restructuring in Khorezm, Uzbekistan. Dordrecht, Netherlands: Springer.

Mather AS. 2007. Recent Asian forest transitions in relation to forest-transition theory. International Forestry Review 9:491-502.

Mathews A. 2011. Instituting Nature: Authority, Expertise and Power in Mexican Forests. Cambridge, MA: MIT Press.

Mattingly DJ. 2001. The home and the world: Domestic service and international networks of caring labour. Annals of the Association of American Geographers 91:370-86.

MiRPAL. 2015. Brief on changes in migration laws of Kazakhstan, Kyrgyzstan, Russia and Tajikistan. [БРИФ об изменениях в миграционном законодательстве Казахстана, Кыргызстана, России и Таджикистана.] Moscow: Migration and Remittance Peer-Assisted Learning Network.

Montefrio MJF, Ortiga YY and Josol M. 2014. Inducing development: Social remittances and the expansion of oil palm. International Migration Review 48(1):216-42.

Mughal A-G. 2006. Migration, Remittances, and Living Standards in Tajikistan. A Report Based on Khatlon Remittances and Living Standards Measurement Survey (KLSS 2005). Stanford University.

$\mathrm{Mu} \mathrm{R}$ and van de Walle D. 2011. Left behind to farm? Women's labor re-allocation in rural China. Labour Economics 18:S83-S97.

Nelson DR, Adger WN and Brown K. 2007. Adaptation to environmental change: Contributions of a resilience framework. Annual Review of Environment and Resources 32:395-419.

Newland K. Circular Migration and Human Development. Human Development Research Paper 2009/42. New York: United Nations Development Programme (UNDP).

Nigmatov U. 1977. Results and prospects of research of the Department of Forestry at the Central Asian Institute of Forestry Research. Tashkent: Central Asian Institute of Forestry Research. 128-43.

[ODIHR] Office for Democratic Institutions and Human Rights. 2012. Social and Economic Inclusion of Women from Migrant Households in Tajikistan. Dushanbe: Organization for Security and Co-operation in Europe. 
Olimova S. 2006. Denezhniy perevod i ih vliyaniye na uroven' zhisni $v$ Khatlonskoy oblasti Respublika Tajikistan. [Money Transfers and Their Impact on Wellbeing in Khatlon Province, Republic of Tajikistan]. Dushanbe: International Organization for Migration (IOM) and Sharq Research Center.

Olimova S and Bosc I. 2003. Labour Migration from Tajikistan. Dushanbe: International Organization for Migration.

Olimova S, Kumar K and Baruah N. 2010. Migration and Development in Tajikistan: Emigration, Return and Diaspora. Moscow: International Labour Office (ILO) Subregional Office for Eastern Europe and Central Asia.

Oxfam. 2009. Reaching a Tipping Point? Climate Change and Poverty in Tajikistan. Dushanbe: Oxfam International.

Padalko VV. 1980. Requirements for use and management of land resources of the state forest lands in the Tajik SSR. Dushanbe: Donish.

Padoch C and Peluso NL. 2003. Borneo in Transition: People, Forest. Conservation, and Development. Kuala Lumpur: Oxford University Press.

Padoch C, Brondizio E, Costa S, Pinedo-Vasquez M, Sears RR and Siqueira A. 2008. Urban forest and rural cities: Multi-sited households, consumption patterns, and forest resources in Amazonia. Ecology and Society 13(2):2.

Parreñas RS. 2001. Servants of Globalization: Women, Migration and Domestic Work. Stanford, CA: Stanford University Press.

Perch-Nielsen SL, Bättig MB and Imboden D. 2008. Exploring the link between climate change and migration. Climatic Change 91:375-93.

Radel C and Schmook B. 2008. Male transnational migration and its linkages to land-use change in a Southern Campeche Ejido. Journal of Latin American Geography 7(2):59-83.

Radel C, Schmook B and McCandless S. 2010. Environment, transnational labor migration, and gender: Case studies from southern Yucatan, Mexico and Vermont, USA. Population and Environment 32(2-3):177-97.

Radel C, Schmook B, Mcevoy J, Mendez C and Petrzelka P. 2012. Labour migration and gendered agricultural relations: the feminization of agriculture in the Ejidal sector of Calakmul, Mexico. Journal of Agrarian Change 12(1):98-119.

Rankin KN. 2004. The Cultural Politics of Markets Economic Liberalization and Social Change in Nepal. London: Pluto Press.
Rain D. 1999. Eaters of the Dry Season. New York: Westview Press.

Reeves M. 2011. Staying put? Towards a relational politics of mobility at a time of migration. Central Asian Survey 30(3-4):555-76.

Reeves M. 2014. Border Work: Spatial Lives of the State in Rural Central Asia. Ithaca: Cornell University Press.

[RFE/RL] Radio Free Europe/Radio Liberty. 9 May 2010. Three Russian Skinheads Found "Guilty" of Murder In Nizhny Novgorod. Radio Free Europe/ Radio Liberty. Accessed 24 August 2016. http:// www.rferl.org/a/Three_Russian_Skinheads_ Found_Guilty_Of_Murder_In_Nizhny_ Novgorod_/2036693.html

Rowe WC. 2009. "Kitchen gardens" in Tajikistan: the economic and cultural importance of smallscale private property in a post-Soviet society. Human Ecology 37:691-703.

Rubinov I. 2014. Migrant assemblages: building postsocialist households with Kyrgyz remittances. Anthropological Quarterly 87(1):183-215.

Rudel TK, Bates D and Machinguiashi R. 2002. A tropical forest transition? Agricultural change, out-migration, and secondary forests in the Ecuadorian Amazon. Annals of the Association of American Geographers 92(1):87-102.

Ryazantsev SV. 2013. Labor migration in Russia: old problems and new ways to solve them. [Трудовая иммиграция в России: старые проблемы и новые подходы крешению]. Bulletin of St. Petersburg University 5(1):1-19.

Scoones I. 1998. Sustainable Rural Livelihoods: A Framework for Analysis. Brighton: Institute for Development Studies.

Skeldon R. 2006 Interlinkages between internal and international migration and development in Asian Region. Population, Space and Place 12:15-30.

Tadjbakhsh S. 1996. The Women's Economic Survey of Tajikistan. Dushanbe: Relief International.

Tajik Meteorology. 2007. Glaciers of Tajikistan and Global Warming. Mahmadaliev B, ed. Dushanbe: Agency on Hydrometeorology, the Republic of Tajikistan and UNEP/GRID-Arendal.

TAJSTAT. 2015a. "СТАТИСТИЧЕСКИЙ СБОРНИК: ЧИСЛЕННОСТЬ НАСЕЛЕНИЯ РЕСПУБЛИКИ ТАДЖИКИСТ АН НА 1 ЯНВАРЯ 2015 ГОДА." [Statistical Compilation: The Population of the Republic of Tajikistan on January 1, 2015]. Dushanbe: Tajikistan State Statistical Committee. 
TAJSTAT. 2015b. "ОСНОВНЫЕ ПОКАЗ АТЕЛИ ОБСЛЕДОВАНИЯ БЮДЖЕТОВ ДОМАШНИХ ХОЗЯЙСТВ РЕСПУБЛИКИ ТАДЖИКИСТ АН." [The Main Indicators of a Survey of Household Budgets in the Republic of Tajikistan]. Dushanbe: Tajikistan State Statistical Committee.

TAJSTAT. 2015с. Охрана окружатошейксреды в Республике Таджикистан (статистический сборник). [Environmental Protection in the Republic of Tajikistan (Statistical Compilation)]. Dushanbe: Tajikistan State Statistical Committee.

Taylor J. 1999. The new economics of labour migration and the role of remittances in the migration process. International Migration 37(1):63-88.

Theesfeld I and Klümper F. 2016. Interplay between structural change in Central Asian agriculture and institutional scarcity of land and water: evidence from Tajikistan. Zeitschrift für Wirtschaftsgeographie 60(1-2):81-96.

Thieme S. 2008. Living in transition: How Kyrgyz women juggle their different roles in a multi-local setting. Gender, Technology and Development 12(3):325-45.

Tiemoko R. 2004. Migration, return and socioeconomic change in West Africa: the role of family. Population, Space and Place 10:155-74.

Tsing AL. 2004. Friction: An Ethnography of Global Connections. Princeton University Press.

Tursunov H and Ibraimov B. 2014. Russian Blacklist Keeps Central Asian Migrants Out. Accessed 25 August 2016. www.eurasianet.org/node/68184

Tyner JA. 1996. The gendering of Philippine international labor migration. Professional Geographer 48:405-16.
[UNDP] United Nations Development Programme. 2015. Labour Migration, Remittances, and Human Development in Central Asia. Central Asia Human Development Series.

[UNICEF] United Nations Children's Fund. 2014. The State of the World's Children. New York: UNICEF.

[USAID] United States Agency for International Development. 2010. Property rights and resource governance: Tajikistan. Dushanbe: US Agency for International Development.

Vihrestok SP and Padalko VV. 1983. Rational Use, Protection and Development of Forest Resources in Tajikistan. Dushanbe: TadjikNIINTI.

Wölcke J, Wegner N and Bulbulshoev U. 2013. Vulnerability Assessment of the Forestry Ecosystem in Vanj District (Tajikistan). Dushanbe: Deutsche Gesellschaft für Internationale Zusammenarbeit (GIZ).

Wong M. 2006. The gendered politics of remittances in Ghanaian transnational families. Economic Geography 82(4):355-81.

World Bank. 2016. Migration and Remittances Factbook 2016. Washington: World Bank.

World Bank. 24 September 2015. Migration and Remittances Data. Brief. Accessed 1 July 2016. www.worldbank.org/en/topic/ migrationremittancesdiasporaissues/brief/ migration-remittances-data

Yeoh BSA, Huang S and Lam T. 2005. Transnationalizing the 'Asian' family: imaginaries, intimacies and strategic intents. Global Networks 5(4):307-15.

Yusupov HS. 25 Years of the Central Asian Research Institute of Forestry. In Proceedings of the Central Asian Research Institute of Forestry Volume X. Tashkent: Uzbekistan Publishers. 3-15. 


\section{Appendix: Data sources in Tajikistan}

There are challenges in accessing relevant and useful data regarding the population, the economy and ecology in Tajikistan. Before addressing these shortfalls, it would be useful to consider some of the valuable sources that are available in the country. Most government statistics on forest cover date to the Soviet era. These official sources have been usefully compiled (Akhmadov 2005, 2009). Observers, however, have reason to doubt that such government statistics adequately reflect actual forest composition (Kirchhoff and Fabian 2010), given that on-the-ground analyses have not been conducted for decades. Most of the forestry, land cadastre and agricultural extension agents use maps that were last updated in the 1980s, if not earlier. For most of the country, those are the only ones available. Satellite imaging could leapfrog some of these gaps but is prohibitively expensive for local agencies to carry out on their own.

For a robust base of social, demographic and economic indicators, the best place to start is the State Committee for Statistics under the President of the Republic of Tajikistan. Fortunately, this committee has established an easily accessible website: www.stats.tj. While the website does not meet all of its intended targets (such as quarterly household budget reports, etc.), it does offer a wealth of information on useful indicators. Many of the documents are translated into Russian and, to a lesser extent, into English. Furthermore, a website dedicated to providing up-to-date costs of agricultural products is also accessible at: www. agroinform.tj. The site has the recent history of different fruits, vegetables and animal products searchable by city, and even bazaar. Both of these websites were established with valuable assistance from foreign aid organizations and are easy to use. However, there are significant limits to these data.

First, it is difficult to compare the recent figures with historical data. The extensive Soviet records have not been digitized and are rarely integrated into recent findings. There is also a massive gap on data from the 1990s, when the country was convulsed by warfare. Therefore, longterm analyses require digging in the National Academy of Sciences Library and other, not easily accessible, archives. While the National Library in Dushanbe has a large collection of resources acquired from across the country into a single (haphazard) repository, the catalogue is not digitized and not everything has made it into the catalogue - nor is everything in the catalogue to be found in the stacks. Second, the data that are available do not clearly define how much agricultural output there is at the household level. Third, there is reason to believe that these data, while offering a good approximation, are not as accurate as they could be. During the author's research, Tajik households gave inaccurate answers to representatives of the local Farmer's Association who came around quarterly to collect taxes and solicit data on agricultural output. Respondents worried that the proper figures might increase their taxes, while others simply quoted figures that were unreasonably high. Thus, more ground truthing of government statistics is required, although a reasonable estimation is still possible. 

CIFOR Occasional Papers contain research results that are significant to tropical forest issues. This content has been peer reviewed internally and externally.

Tajikistan has been the world's most remittance-dependent economy for a decade. While migration processes have been well documented, their effects on ecological systems deserve greater scholarly and policy engagement. This paper considers the impact of wide-spread labor migration on land and forest resources. Changes to Tajikistan's land tenure regime alongside relative stability after a lost decade of civil war and upheaval have created new opportunities for long-term ecological management. Despite a lack of experience and institutional support, Tajik households are beginning to invest in tree crops and expand woodlands. Migrants and sending communities are emerging as important drivers of land use and forest cover in Tajikistan.

\begin{tabular}{|l|l} 
CGIAR & $\begin{array}{l}\text { RESEARCH } \\
\text { PROGRAM ON } \\
\text { Forests, Trees and }\end{array}$ \\
Agroforestry
\end{tabular}

cifor.org
This research was carried out by CIFOR as part of the CGIAR Research Program on Forests, Trees and Agroforestry (FTA). This collaborative program aims to enhance the management and use of forests, agroforestry and tree genetic resources across the landscape from forests to farms. CIFOR leads FTA in partnership with Bioversity International, CATIE, CIRAD, the International Center for Tropical Agriculture and the World Agroforestry Centre.

\section{Fund}

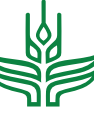

CGIAR 